\title{
It's Not Only What you Say, It's Also How You Say It: The Strategic Use of Campaign Sentiment*
}

\author{
CHARLES CRABTREE ${ }^{\dagger}$ \\ University of Michigan \\ MATT GoLDER ${ }^{\ddagger}$ \\ Pennsylvania State University \\ THOMAS GSCHWEND ${ }^{\S}$ \\ University of Mannheim \\ INDRIĐI H. INDRIĐASON ${ }^{\mathbb{9}}$ \\ University of California, Riverside
}

\begin{abstract}
What explains the type of electoral campaign run by political parties? We provide a new perspective on campaigns that focuses on the strategic use of emotive language. We argue that the level of positive sentiment parties adopt in their campaigns depends on their incumbency status, their policy position, and objective economic conditions. We test these claims with a novel dataset that captures the emotive language used in over 400 party manifestos across eight European countries. As predicted, we find that incumbent parties, particularly incumbent prime ministerial parties, use more positive sentiment than opposition parties. We find that ideologically moderate parties employ higher levels of positive sentiment than extremist parties. And we find that all parties exhibit lower levels of positive sentiment when the economy is performing poorly but that this negative effect is weaker for incumbents. Our analysis has important implications for research on campaign strategies and retrospective voting.
\end{abstract}

*NOTE: We thank James Adams, Nicole Baerg, Jason Eichorst, Sona Golder, Michael Lewis-Beck, Thomas Meyer, Jonathan Nagler, Simone Paolo Ponzetto, Rüdiger Schmitt-Beck, Laron Williams, participants at the 2015 Making Electoral Democracy Work Workshop at Sciences Po (Paris), the 2016 Making Electoral Democracy Work Workshop at the University of Montreal, the 2016 Annual Meeting of the Midwest Political Science Association, the 2016 Annual Meeting of the American Political Science Association, and audiences at the University of Pittsburgh, Rice University, and Texas A\&M University for their helpful comments. We acknowledge financial support for this research from the Social Sciences and Humanities Research Council of Canada. All data and computer code necessary to replicate the results in this analysis will be made publicly available on our webpages on publication. Stata 14 was the statistical package used in this study.

${ }^{\dagger}$ Ph.D. Candidate, Department of Political Science, University of Michigan, 505 South State Street, Ann Arbor, MI 48109. (ccrabtreumich.edu).

${ }^{\ddagger}$ Professor, Department of Political Science, Pennsylvania State University, 306 Pond Lab, University Park, PA 16802 (mgolder@psu.edu).

${ }^{\S}$ Professor, Department of Political Science, University of Mannheim, A 5, 6, D-68131, Mannheim, Germany (gschwendeuni-mannheim.de).

${ }^{\top}$ Corresponding Author: Professor, Department of Political Science, 900 University Avenue, University of California, Riverside, CA 92521 (indridi.indridason@ucr.edu). 
What explains the type of electoral campaign run by political parties? To a large extent, scholars have conceptualized electoral campaigns along two primary dimensions. The first dimension captures campaign content - whether parties compete on policy or valence (Downs, 1957; Ansolabehere and Snyder, 2000; Schofield, 2003; Adams, 2001; Adams, Merrill and Grofman, 2005; Adams, Scheiner and Kawasumi, 2016). The second dimension captures campaign focus — whether parties adopt campaign messages that focus on themselves or their opponents (Skaperdas and Grofman, 1995; Lau and Pomper, 2002; Geer, 2006; Elmelund-Præstekær, 2008, 2010; Hansen and Pedersen, 2008). One aspect of campaigns that is ignored in this two-dimensional framework is campaign sentiment, which refers to the emotive content of campaigns. Whereas campaign content and campaign focus address what parties say and who they say it about, campaign sentiment addresses how they say it.

Scholars are increasingly looking at how the emotive content of campaign messages affects voter behavior (Marcus, Neuman and MacKuen, 2000; Brader, 2006; Huddy and Gunnthorsdottir, 2000; Roseman, Abelson and Ewing, 1986; Weber, Searles and Ridout, 2011; Utych, 2018). The common thread in this literature is that voters are not merely influenced by the substantive content of campaigns but also by their emotive content. Studies have repeatedly shown that electoral campaigns can be manipulated to trigger emotional responses that, in turn, produce predictable changes in voter behavior. This raises a natural question. If campaign sentiment influences voter behavior, political actors should be strategic about its use. Are they? To date, there has been little research that explicitly looks at the strategic use of emotion in election campaigns. What research there is tends to focus on the historically majoritarian systems in the United States and the United Kingdom (Ridout and Searles, 2011; Kosmidis et al., Forthcoming). ${ }^{1}$

In this article, we examine the strategic use of emotive language in European election campaigns. Studies that look at emotion in campaigns often focus on the use of images and music (Huddy and Gunnthorsdottir, 2000; Brader, 2006). However, language can also engender different types of sentiment, such as fear, anxiety, sadness, or optimism (Roseman, Abelson and Ewing, 1986; Pennebaker, 1993; Pennebaker and Francis, 1996). We build on a long tradition that emphasizes how language can shape how individuals perceive the world around them (Edelman, 1964, 1977; Foucault, 1972; Hipt, 1990; Hart, Childers and Lind, 2013). The importance of language is emphasized by Edelman $(1985,10)$, who argues that "political language is political reality." Academic and non-academic observers have recently pointed to Donald Trump's

\footnotetext{
${ }^{1}$ Ridout and Searles (2011) look at the strategic use of emotion in several U.S. Senate races, while Kosmidis et al. (Forthcoming) look at it in U.S. Presidential State of the Union addresses as well as British party manifestos and party leader speeches.
} 
election campaign to highlight the significance that word choice plays in politics (Healy and Habermandec, 2015; Lakoff, 2016). Of particular interest to us is whether parties adopt language that conveys positive or negative sentiment. Campaign messages that include positive emotive language encourage people to adopt a positive frame when evaluating the current state of the world, whereas campaign messages that include negative emotive language have the opposite effect.

Our theory is situated in the retrospective voting literature. Models of retrospective voting assume that individuals base their vote choice on the state of the world at election time, something that is usually attributed to incumbent performance in office. Though not necessary, the state of the world is typically understood in economic terms (Norpoth, Lewis-Beck and Lafay, 1991; Lewis-Beck and Stegmaier, 2000; van der Brug, van der Eijk and Franklin, 2007; Nadeau, Lewis-Beck and Éric Bélanger, 2013). The basic intuition is that people will vote for the incumbent when economic performance is above some threshold but switch to the opposition when this is not the case. The ability of individuals to vote retrospectively depends on a variety of contextual factors such as the ease with which they can attribute responsibility for economic performance to individual incumbent parties (Powell and Whitten, 1993; Duch and Stevenson, 2008). The core insight, though, is that vote choice is determined by how individuals perceive the state of the world.

Extant research largely assumes that voter perceptions are related to objective economic reality. In effect, individuals are expected to have a more positive view of the world and, thus, evaluate the incumbent more favorably when, say, the unemployment rate is low. What tends to be overlooked, though, is that political elites can exert agency and shape retrospective voting by using their campaign messages to frame how individuals evaluate economic reality. Scholars have recently shown that parties strategically use campaign messages to emphasize or deemphasize economic issues (Vavreck, 2009; Williams, Seki and Whitten, 2016). By altering the salience of economic issues, parties can influence how voters weigh economic conditions in their voting calculus. In this particular account, parties do not seek to change how voters perceive objective economic reality but rather how much they care about it.

We argue that a complementary strategy parties can adopt involves using emotive language to alter how individuals actually perceive economic conditions. Objective reality can be understood very differently depending on how it is framed. For example, a message stating that "the economic outlook is positive, with employment increasing by 150,000 " provides a much more positive frame for viewing the world than a message stating that "employment increased by 150,000." Such differences in the strategic use of positive and negative emotive language can substantially influence how individuals perceive the world (Chong and 
Druckman, 2007; Zaller, 1992; Utych, 2018) and, hence, how they vote. Our theoretical account provides an explanation for why supporters of different parties often hold varying perceptions of the same objective economic conditions (MacKuen, Erikson and Stimson, 1989; Duch, Palmer and Anderson, 2000; Anderson, 2007; Enns, Kellstedt and McAvoy, 2012).

Our retrospective voting framework suggests that the level of positive campaign sentiment exhibited by political parties should depend on their incumbency status, their policy position, and objective economic conditions. Incumbent parties, particularly prime ministerial parties, should exhibit greater positive sentiment in their campaigns than opposition parties. This is because incumbents are expected to gain support when voters have a more positive view of the world. The campaigns of extremist parties should be characterized by less positive sentiment than those of more moderate parties. This is because extremist parties are expected to gain support when the world is viewed in a particularly negative light. The language that parties adopt cannot diverge too far from reality, though, otherwise voters will become suspicious. This suggests that the campaign sentiment of all political parties will be tied to some extent to objective economic conditions. Thus, parties should exhibit greater positive sentiment when economic conditions are good. This increase in positive sentiment, though, should be greater for incumbent parties, as they are the prime beneficiaries of improved economic conditions.

We test our claims using a novel dataset we constructed of the emotive language used in over 400 party manifestos across eight European countries from 1980 to 2012. Party manifestos are obviously only one type of campaign message. However, they are of particular relevance as they contain the campaign messages parties have strategically chosen to present to voters, a look that is not filtered through the lens of the media. Moreover, party manifestos outline the overarching campaign strategy of parties in a way that, say, party press releases, which emerge irregularly throughout the campaign in response to ad hoc developments, might not. Historically, scholars have used manifestos to examine issue salience and party positions (Budge et al., 2001). Our focus on the strategic use of emotive discourse thus helps to extend the use of manifestos in a new direction (Breeze, 2011; Kosmidis et al., Forthcoming). Our empirical results strongly support our theoretical expectations and have important implications for the literatures on both campaign strategies and retrospective voting. 


\section{Theory}

Existing research largely focuses on two dimensions of election campaigns. The first dimension, campaign content, has to do with whether parties compete on policy or valence. Early models of electoral competition were purely spatial and focused on the policy positions adopted by each party (Downs, 1957; Wittman, 1973). More recent models incorporate non-spatial valence factors such as party competence, integrity, and experience (Ansolabehere and Snyder, 2000; Schofield, 2003; Adams, 2001; Adams, Merrill and Grofman, 2005). The second dimension, campaign focus, concerns whether parties focus their campaign messages on themselves or their opponents (Skaperdas and Grofman, 1995; Lau and Pomper, 2002; Elmelund-Præstekær, 2008, 2010; Hansen and Pedersen, 2008; Lau and Rovner, 2009). This dimension is sometimes referred to as campaign tone, with messages that focus on one's own party considered positive and those that focus on other parties considered negative (Geer, 2006). In our opinion, this terminology is confusing as it mixes up the 'focus' or target of campaign messages with the 'tone' or sentiment of campaign messages, two things that are conceptually and empirically distinct (Ridout and Franz, 2011).

A key aspect of electoral campaigns that has traditionally been overlooked in the existing literature is campaign sentiment. Whereas campaign content and campaign focus address what parties say and who they say it about, campaign sentiment addresses the emotive content of campaigns and has to do with how parties say things. Empirically, there is considerable variation in the use of emotion across both the campaign focus and campaign content dimensions. It is known, for example, that campaigns that focus on one's own party do not always contain positive emotive content and those that focus on other parties do not always contain negative emotive content (Ridout and Searles, 2011). In their analysis of campaign messages, Ridout and Franz $(2011,101)$ conclude that '[campaign focus] and emotional appeals are not one and the same." Studies also reveal significant variation in the use of emotion across the campaign content dimension (Ridout and Franz, 2011, 94-95). We know, for example, that parties use emotional appeals when discussing both policy and valence issues. Importantly, Utych (2018) finds that altering the emotive nature of the language used to describe political candidates influences how these candidates are evaluated even after controlling for the substantive content and focus of the candidate descriptions. Thus, both conceptually and empirically, campaign sentiment represents a third and distinct dimension of electoral campaigns.

It is widely recognized that political actors make emotional appeals to the public (Hart, Childers and Lind, 2013), and recent research indicates that these appeals can have a significant effect on voter behavior 
(Marcus, 2000; Brader and Marcus, 2013). For example, Brader (2005, 2006) finds that campaigns evoking fear cause individuals to reconsider their political choices, whereas those evoking enthusiasm cause them to stick with their pre-existing preferences. As another example, Utych (2018) finds that political candidates are evaluated more negatively when they are described using negative emotive language than when they are described using neutral emotive language. As a whole, this research is consistent with the idea that individuals process information differently depending on their emotional mood (Schwarz, 2000).

If campaigns can be manipulated to elicit particular emotions and thereby influence voter behavior in predictable ways, as the existing literature suggests, then we should expect political actors to be strategic in their use of emotion. To date, there has been no cross-national research on whether and how these actors strategically employ emotion in multiparty elections. In this article, we argue that parties strategically use emotion in their campaign messages to frame the state of the world in either a positive or negative light.

The incentive to frame the state of the world in a particular way can be tied to the logic underpinning models of retrospective voting. These models assume that an individual's vote choice depends on how they view the world. The state of the world is understood to be determined, at least partially, by the incumbent's performance in office. Individuals reward the incumbent when they perceive the state of the world to be good, but punish her when they perceive it to be poor. Though not necessary, the state of the world is usually understood in terms of the economy.

If vote choice is influenced by how we perceive the state of the world, then parties have incentives to shape those perceptions through their campaigns (Vavreck, 2009). One way parties can do this is through the substantive content of their campaign messages. For example, a party might highlight how its own policies and valence characteristics can change the world for the better, or it might emphasize how those of its competitors would make things worse. A complementary way to influence how voters perceive the world, though, is through the emotive content of their campaigns. The use of positive campaign sentiment can encourage voters to adopt a positive frame when evaluating the state of the world. In contrast, the use of negative campaign sentiment can encourage voters to adopt a negative frame when assessing the world around them (Utych, 2018). In effect, parties can influence perceptions of the world and, hence, vote choice not only through the substantive content of their campaign messages but also through the emotive content of their campaigns. Indeed, it seems plausible that voters are better at assessing the overall sentiment in campaign messages than the often detailed substantive positions that are staked out in these messages. ${ }^{2}$

\footnotetext{
${ }^{2}$ Importantly, research has shown that emotional responses to the economic state of the world have a particularly strong impact
} 
In this regard, incumbent parties should exhibit higher levels of positive sentiment in their campaign messages than opposition parties. This is because incumbents, who are perceived as responsible for the current state of the world, can expect to gain support when voters view things in a more positive light.

Incumbent Party Hypothesis: Incumbent parties use higher levels of positive sentiment in their campaign messages than opposition parties.

When there is only one party in government, it is clear who voters should hold responsible. It is much less clear, though, who they should hold responsible when there is a coalition government (Powell and Whitten, 1993; Duch, Przepiorka and Stevenson, 2015). That the prime minister is the most visible member of the government and is widely recognized as the agenda setter (Norpoth and Gschwend, 2010; Duch and Stevenson, 2013) suggests that voters will hold the prime ministerial party more responsible than its coalition partners. Indeed, empirical evidence consistently shows that the economic vote for the prime ministerial party is large compared to that of other governmental parties (Duch and Stevenson, 2008; Debus, Stegmaier and Tosun, 2014). A consequence is that prime ministerial parties have a particularly strong incentive to portray the world in a positive light and should therefore exhibit even higher levels of positive campaign sentiment than their coalition partners. ${ }^{3}$

Prime Ministerial Party Hypothesis: Prime ministerial parties use higher levels of positive sentiment in their campaign messages than their coalition partners.

The level of positive sentiment parties exhibit in their campaigns should also depend on their policy position. Even controlling for their incumbency status, we would expect ideologically extreme parties to exhibit less positive sentiment than ideologically moderate parties. This is because voters are more likely to reject moderate parties and turn to more extreme parties when they perceive the state of the world to be particularly bad (King et al., 2013). Radical parties in Europe, for example, propose 'root and branch' reform of the political and economic system and many adopt populist rhetoric that holds all moderate parties responsible for society's ills (Mudde, 2007; Golder, 2016). These parties do not just want voters to punish the incumbent, they want voters to abandon the mainstream parties altogether. This is most likely to occur when the current state of affairs is considered particularly problematic. This reasoning fits with media accounts linking the recent success of left- and right-wing radical parties to Europe's economic crisis.

on how individuals evaluate political actors (Conover and Feldman, 1986).

${ }^{3}$ Some scholars suggest that voters may also attribute responsibility for the state of the world to the finance ministry party (Williams, Seki and Whitten, 2016). However, the empirical support for this claim is rather mixed (Duch and Stevenson, 2008; Debus, Stegmaier and Tosun, 2014). In our own analyses in Online Appendix A, we find little evidence that parties controlling the finance ministry use higher levels of positive campaign sentiment than their coalition partners. 
Extreme Ideology Hypothesis: Ideologically extreme parties use lower levels of positive sentiment in their campaign messages than ideologically moderate parties.

The level of positive sentiment parties exhibit in their campaigns should also vary with objective measures of the state of the world. While parties will try to use the emotive content of their campaigns to get voters to see the world through a particular frame, the extent to which they can do this is constrained by economic reality (Parker-Stephen, 2013; Pardos-Prado and Sagarzazu, 2016). Campaign messages that are too positive when times are bad or too negative when times are good are likely to be ignored by voters as they deviate from their own personal experiences (Ansolabehere, 2006). Moreover, voters are likely to punish parties if the campaign sentiment they adopt paints a false, misleading, or 'out-of-touch' picture. While there is some debate as to the size of these costs, there is evidence that honesty and integrity are considered positive attributes and that political actors are aware of the reputational costs associated with misleading voters (Nyhan and Reifler, 2015). Given this, we should expect the level of positive sentiment exhibited by all parties to vary in line with objective measures of the economy.

Economic Performance Hypothesis: Campaign messages will exhibit lower levels of positive sentiment when the economy is performing poorly than when it is performing well.

There are reasons to believe that economic conditions and a party's incumbency status interact to determine levels of positive campaign sentiment. The negative effect of poor economic performance on positive campaign sentiment should differ depending on whether a party is in government or not. This is because incumbent parties have an incentive to downplay the poor performance of the economy, whereas opposition parties have an incentive to exaggerate it.

Conditional Economic Performance Hypothesis: Campaign messages will exhibit lower levels of positive sentiment when the economy is performing poorly than when it is performing well. This negative effect of poor economic performance is weaker for incumbent parties than for opposition parties.

All conditional claims are symmetric (Berry, Golder and Milton, 2012), and the Conditional Economic Performance Hypothesis logically implies that the effect of a party's incumbency status on positive campaign sentiment depends on how well the economy is performing. Incumbent parties should always use more positive sentiment in their campaigns irrespective of the state of the economy. However, the positive effect of incumbency should be greater when the economy is performing poorly. This is because opposition parties will want to use particularly negative emotive language relative to incumbent parties in these circumstances as a way of emphasizing the poor state of the world. 
Conditional Incumbent Party Hypothesis: Incumbent parties use higher levels of positive sentiment in their campaign messages than opposition parties. This positive effect of incumbency is greater when the economy is performing poorly than when it is performing well.

\section{Empirical Analysis}

We test our hypotheses by looking at the strategic use of emotive language in European party manifestos. While much of the research on emotion and politics looks at the use of images and music, we return to an older tradition that examines how language shapes perceptions of the political world (Edelman, 1964, 1977). As studies in linguistics and psychology have shown, language can engender different emotions (Roseman, Abelson and Ewing, 1986; Pennebaker, 1993; Pennebaker and Francis, 1996), and thereby influence the frame through which the world is perceived. By focusing on emotive language, our analysis contributes to an emerging literature looking at the use of emotion in political discourse (Rheault et al., 2016) and helps extend the study of manifestos beyond their traditional use as a means to examine issue salience and party positions (Breeze, 2011; Kosmidis et al., Forthcoming).

\section{Party Manifestos}

Manifestos obviously represent only one type of campaign message. However, they are perhaps the most important type of campaign message as they contain each party's official platform. Parties spend considerable time deciding which issues to include in their manifestos and how much space to give them (Janda et al., 1995; Green and Hobolt, 2008; Dolezal et al., 2012; Däubler, 2012a,b). We suspect that parties are just as strategic about the type of language they include (Breeze, 2011). This is because "parties make determined efforts to campaign based on their ... manifestos", and because the language and campaign messages found in manifestos are repeated when parties "communicate to the public via other avenues, such as campaign advertisements, party elites' campaign speeches, and media interviews" (Adams, Ezrow and Somer-Topcu, 2011, 372). A consequence of this last point is that voters are exposed to the campaign messages in manifestos even if they don't explicitly read these documents. The importance of manifestos is also reflected in the fact that they play an important role in the government formation process (Däubler, 2012a) and that parties make concerted efforts to implement their manifesto campaign pledges (Thomson et al., 2017).

Although it is often assumed that the electorate is uninterested in party manifestos, some voters do consult these documents. The German Election Study, for example, found that $32 \%$ of the public claimed to 
Figure 1: Google Searches for Party Names and Party Manifestos in the United Kingdom, 2004-2017
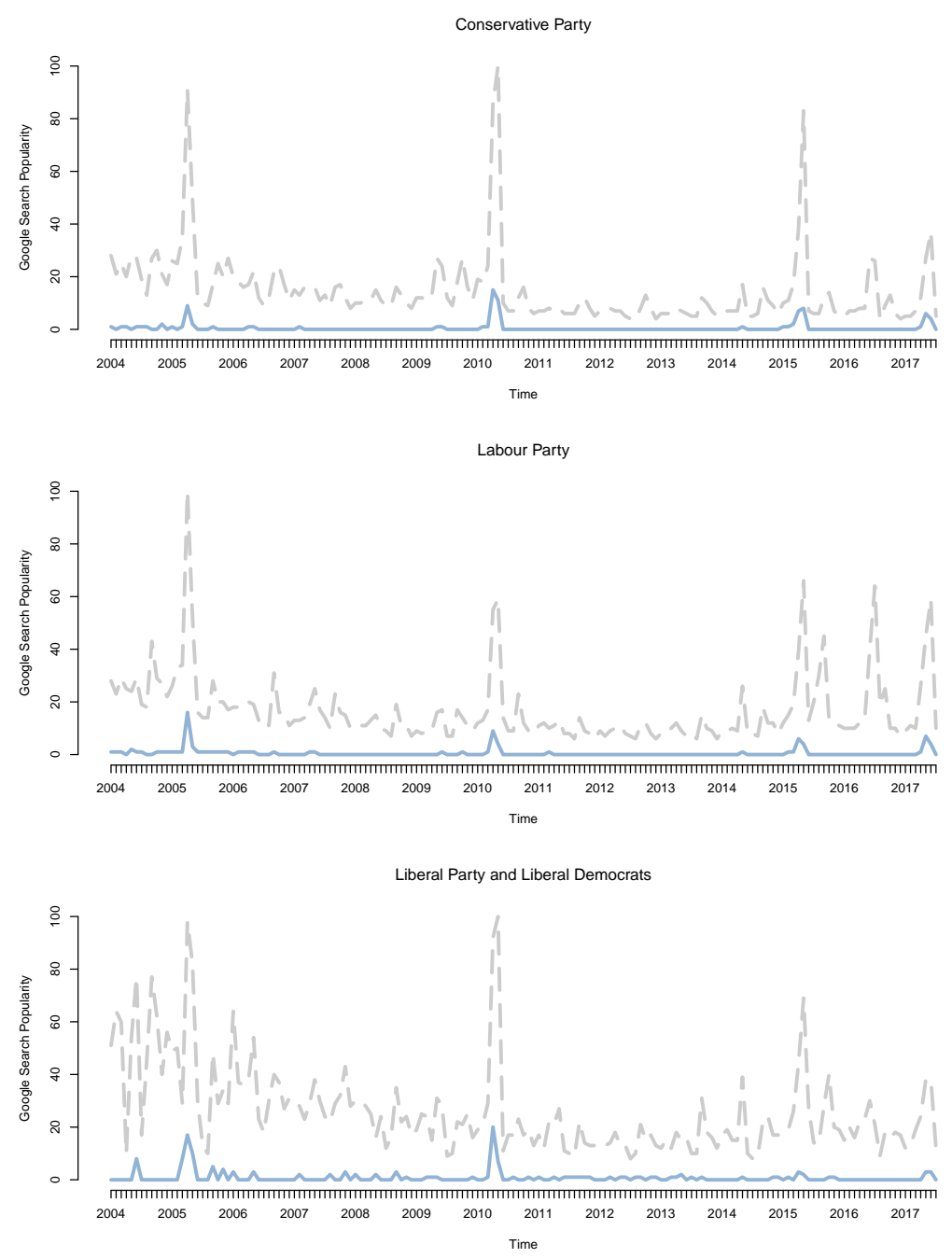

Note: Figure 1 indicates the frequency with which individuals used Google to search for the Conservative Party, the Labour Party, and the Liberal Party (dashed lines) relative to the frequency with which they used it to search for party manifestos (solid lines).

have read manifestos prior to the 2013 elections (D'Ottavio and Saalfeld, 2016). Similarly, a poll in the UK found that $27 \%$ of respondents claimed to have looked at party manifestos leading up to the 2010 elections (Dathan, 2015). Further evidence voters actively seek out manifestos comes from online searches for these documents. Figure 1 presents data from the UK between 2004 and 2017 showing the frequency with which people used Google to search for the Conservative Party, the Labour Party, and the Liberal Party (dashed gray lines) relative to the frequency with which they used it to search for party manifestos (solid blue lines). ${ }^{4}$

\footnotetext{
${ }^{4} \mathrm{~A}$ limitation of Google search term data is that it provides a relative, rather than absolute, measure of search term traffic. This means we can only interpret the data for a party manifesto search term relative to some second search term. In Figure 1 we use a party's name as a natural second 'anchor' search term. The vertical axes, Google search popularity, are scaled from 0 to 100 , so that 100 represents the highest number of searches in a month that were conducted for the anchor search term between 2004
} 
Naturally, individuals are much more likely to use a party name as their search term than a party manifesto. The important thing to note, though, is that the relative frequency with which people searched for manifestos increased substantially (the blue upticks) just prior to the May 2005, 2010, 2015 and June 2017 elections. $^{5}$ Significantly, those individuals who actively seek out manifestos tend to be more politically sophisticated than the average voter and thus opinion makers in their social networks (Kenny, 1998; Christakis and Fowler, 2009). This again means we can expect the impact of the emotive language used in manifestos to be felt far beyond the set of individuals who explicitly read these documents. ${ }^{6}$

Manifestos have at least four desirable properties for testing our hypotheses. First, they provide parties with an opportunity to place their campaign strategy before voters in a carefully scripted way that is unfiltered by the media. This is important because our theory focuses on the strategic choices parties make with respect to their use of emotive language, and not on how party campaign messages are portrayed by the media. Parties do not exert the same degree of control over other types of campaign messages. For example, the content and style of televised debates is rarely under the control of individual parties, and party leaders often find themselves responding on the fly to the issues and questions raised by, and language and gestures used by, debate moderators, political opponents, and audience members. Second, manifestos outline the overarching campaign strategy of parties in a way that, say, party press releases or party election broadcasts, which often emerge irregularly throughout the campaign in response to ad hoc developments, might not. Third, manifestos are a type of campaign message that is used across Europe, thereby facilitating cross-national comparison. This is not true of other forms of campaign message. Unlike many countries, for example, Switzerland forbids political advertising on television and the radio, and parties generally conduct their campaigns in newspapers and on election posters. Other countries allow televised advertising, but there is considerable cross-national heterogeneity in how it is regulated (Holtz-Bacha and Just, 2017). Similar variation exists when it comes to election debates or the extent to which parties and their candidates use websites and social media (Gibson, 2004; Gibson and Römmele, 2009). Fourth, European manifestos

and 2017. The number of searches per month for both the party name search term and the party manifesto search term are then measured relative to this 'highest' value. Thus, a Google search popularity score of 20 indicates that people used this search term at one fifth the rate that they used the most popular search term in its most 'popular' month.

${ }^{5}$ Given that many people access manifestos directly from party websites, which they reach by searching on a party name, the information shown in Figure 1 is almost certainly an underestimate of the extent to which voters seek out manifestos.

${ }^{6} \mathrm{We}$ recognize there is no strong consensus as to the overall reach of manifestos into the electorate. Importantly, if only a few voters are exposed to the information in manifestos, then this works against us finding support for our hypotheses. This is because our theory is premised on parties having strategic incentives to use emotive language to shape voter perceptions of the state of the world. If the campaign messages in manifestos are not expected to reach voters, parties will have fewer incentives to use emotive language strategically and it becomes less likely we will find the patterns we predict in the data. In effect, party manifestos may well represent a difficult case for us. 
are available for a long period of time, something that allows us to examine how the same parties change their use of campaign sentiment as they move in and out of office. ${ }^{7}$

Our dataset comprises 421 manifestos from 108 distinct parties between 1980 and 2012 from eight countries: France, Germany, Ireland, Italy, Netherlands, Portugal, Spain, and the United Kingdom. Existing studies that examine the use of emotion in election campaigns typically focus on individual countries, especially the United States and the United Kingdom (Breeze, 2011; Rheault et al., 2016; Kosmidis et al., Forthcoming). Our analysis is the first to adopt an explicitly cross-national perspective. We focus on this particular set of countries largely for computational reasons - the method of sentiment analysis we use only works for manifestos written in English, Dutch, French, German, Italian, Portuguese, and Spanish. Almost all of our countries have experienced coalition governments. This is important as our Prime Ministerial Party Hypothesis requires us to test the claim that prime ministerial parties exhibit higher levels of positive sentiment than their coalition partners. Party manifestos were obtained from the Political Documents Archive (Benoit, Bräuninger and Debus, 2009), which includes manifestos for all parties that win at least $1 \%$ of the valid votes in the election for which the manifesto was written. Our corpus of manifestos spans 70 national elections. The average manifesto contains 21,979 words and 879 sentences. In total, our manifestos comprise $9,274,954$ words.

Consistent with salience theory, research has shown that parties rarely use manifestos to target their opponents (Budge and Farlie, 1983a,b; Dolezal et al., 2014). Instead, they use them to focus on their own policies. As we demonstrate, though, manifestos exhibit considerable variation in the extent to which they use positive and negative emotive language. This provides further support for our earlier claim that campaign sentiment is conceptually and empirically distinct from both campaign focus and campaign content.

\section{Measuring Campaign Sentiment}

We measure campaign sentiment using the Linguistic Inquiry and Word Count (LIWC) program (Pennebaker, Booth and Francis, 2007). ${ }^{8}$ This is a tool for conducting automatic sentiment analysis widely used in the social sciences and increasingly in political science (Bryan and Ringsmuth, 2016; Corley and

\footnotetext{
${ }^{7}$ Although manifestos have several desirable properties for testing our hypotheses, we do examine the strategic use of emotive language in other types of campaign messages - televised election debates, party election broadcasts, and party websites - in a case study of the 2013 German elections in Online Appendix D. The results are remarkably similar to those presented in the main text and in line with our theoretical predictions. Among other things, these supplementary analyses provide further support for the claim that parties adopt a consistent message across different forms of campaign media (Adams, Ezrow and Somer-Topcu, 2011).

${ }^{8}$ LIWC can be implemented directly or via quanteda, an R package designed to help manage and analyze text (Benoit, 2017).
} 
Wedeking, 2014; Owens and Wedeking, 2011, 2012; Settle et al., 2016). The program scans documents and uses a language-specific dictionary to assign each word to one or more categories. ${ }^{9}$ Each category groups words that share similar linguistic dimensions. For example, categories might be pronouns or verbs, psychological constructs such as affect or cognition, concern categories such as work or home, or linguistic dimensions. As the program scans a document, it increments the count of words belonging to each category. It then divides the final counts by the total number of words in the document, creating a measure of the percentage of words belonging to each category. As an example, LIWC could analyze a document and report that $15 \%$ of the words are verbs. Researchers have repeatedly verified that the LIWC categories accurately measure these underlying linguistic constructs. In particular, research has shown that LIWC categories have strong predictive, concurrent, and convergent validity (Pennebaker and Francis, 1996; Alpers et al., 2005; Pennebaker, Booth and Francis, 2007). ${ }^{10}$

Two LIWC categories are of particular interest: (i) positive emotive words and (ii) negative emotive words. Each category is mutually exclusive in that words in one category do not appear in the other. Most words we use have no emotional valence and, as a result, the scores for both categories are relatively low in all types of documents. In Table 1, we show the mean percentage of positive and negative words for different types of text written in English. The mean percentage of positive words ranges from 1.33 (scientific articles) to 3.72 (blogs). The mean percentage of negative words ranges from 0.71 (daily writing) to 2.67 (emotion writing). In our sample of manifestos, the mean percentage of positive words is $3.02(\sigma=1.91)$ and the mean percentage of negative words is $1.32(\sigma=0.79) .{ }^{11}$

To better understand these two categories, consider the English dictionary. The positive words category contains 406 words such as efficient, good, or improve. The sentence below comes from the UK Conservative Party's manifesto in 1987. Positive words are shown in bold.

\footnotetext{
${ }^{9}$ The English dictionary includes almost 4,500 words or word stems. It has been estimated that, on average, these words account for over $86 \%$ of the words people use in various forms of writing and speech (Pennebaker et al., 2007, 10).

${ }^{10}$ LIWC can clearly misclassify individual words, particularly those that are used in an ironic or sarcastic manner (Tausczik and Pennebaker, 2010, 30). However, these errors rarely affect results at the document level as LIWC uses a probabilistic model that classifies words based on how they are most commonly used. LIWC does better at analyzing longer texts than shorter ones. That the average manifesto contains about 22,000 words means that LIWC should provide accurate results in our particular application. Ultimately, concerns with the misclassification of words relate to potential measurement error in our dependent variable. Significantly, this type of measurement error does not affect the unbiasedness of one's parameter estimates; it simply leads to larger variances than would otherwise be the case. In other words, any measurement error resulting from the LIWC program will only make it harder for us to find statistically significant results. Finally, we recognize there is other software that can conduct automatic sentiment analysis, such as AFINN, ANEW, Stanfords NLP, and WordNet-Affect. However, these programs are limited to only a few languages, typically English and Chinese, and do not have LIWC's long history of validation both within and across languages.

${ }^{11}$ More descriptive information for our manifestos can be found in Online Appendix B, which contains histograms of positive and negative words scores.
} 
Table 1: Mean Positive Words Scores and Negative Words Scores

\begin{tabular}{lccccccc}
\hline & Party Manifestos & Emotion Writing & Control Writing & Scientific Articles & Blogs & Novels & Talking \\
& & & & & & & \\
\hline Positive Words & 3.02 & 3.28 & 1.83 & 1.33 & 3.72 & 2.86 & 3.42 \\
Negative Words & 1.32 & 2.67 & 0.71 & 0.84 & 2.07 & 1.98 & 1.49 \\
\hline
\end{tabular}

Note: The first column contains the mean percentages from our party manifestos. The remaining columns present the mean percentages across a range of English language texts (Pennebaker et al., 2007, 9-13). 'Emotion writing' refers to writing that addresses deeply emotional topics, whereas 'control writing' refers to writing that addresses non-emotional topics, such as plans for the day or everyday objects.

In the last eight years our country has changed - changed for the better.

If we were to code this sentence as the whole document, the positive words score would be 7.69 , indicating that $1 / 13=7.69 \%$ of the words are positive. The negative words category contains 499 words, such as beaten, danger, or unimpressive. The sentence below comes from the UK Liberal Party's manifesto in 1987. Negative words are underlined and shown in bold.

\section{Too many elderly people suffer from isolation, fear and cold.}

If we were to code this sentence as the whole document, the negative words score would be 30.00 , indicating that $3 / 10=30.00 \%$ of the words are negative.

The levels of positive or negative word scores vary across different languages. This is illustrated by the boxplots shown in the upper portion of Figure 2. The manifestos written in Portuguese, for example, exhibit much higher levels of both positive and negative words than the manifestos written in other languages. In our upcoming analyses, we take account of the heterogeneity across languages in the use of positive and negative words through the use of language fixed effects.

Ultimately, our hypotheses are concerned with the overall level of positive sentiment exhibited in a manifesto. Since manifestos contain both positive and negative words, our dependent variable, Positive Sentiment, is calculated as the positive words score minus the negative words score for a given manifesto. The theoretical range for our dependent variable is $+100 \%$ if all words were positive to $-100 \%$ if all words were negative. In line with the fact that most words lack emotional valence, the observed range for Positive Sentiment is $-0.68 \%$ to $7.60 \%$; the mean is $1.70 \%$ and the standard deviation is $1.45 \%$. The lower portion of Figure 2 provides boxplots for Positive Sentiment. The manifestos written in Dutch have the lowest mean levels of Positive Sentiment, while those written in Portuguese have the highest. 
Figure 2: Positive Words Scores, Negative Words Scores, and Positive Sentiment by Language

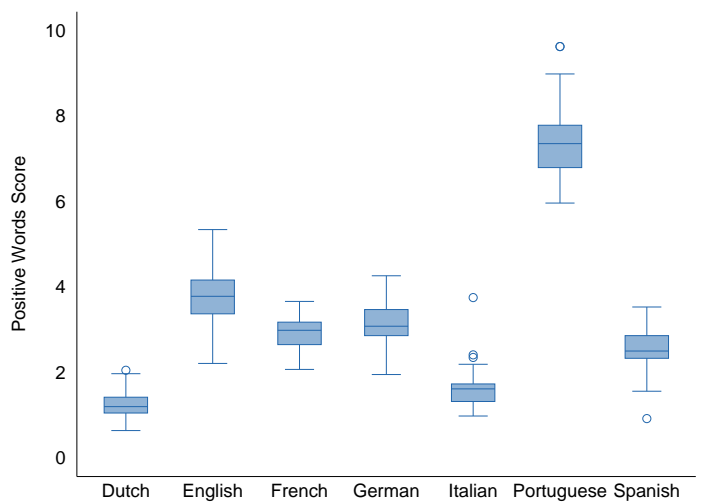

(a) Positive Words Score

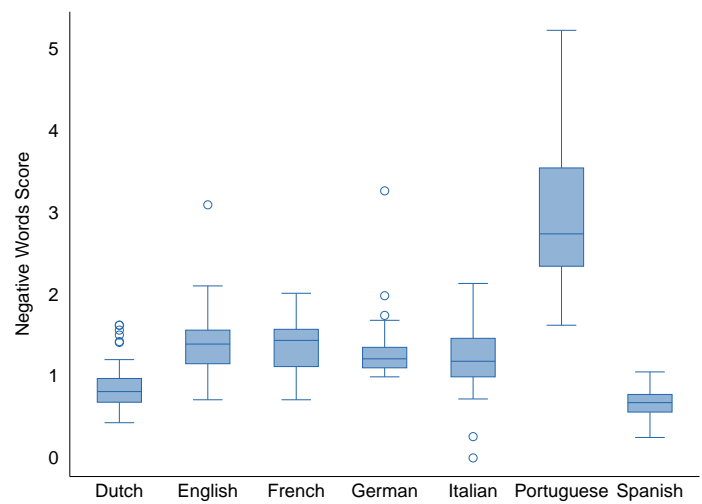

(b) Negative Words Score

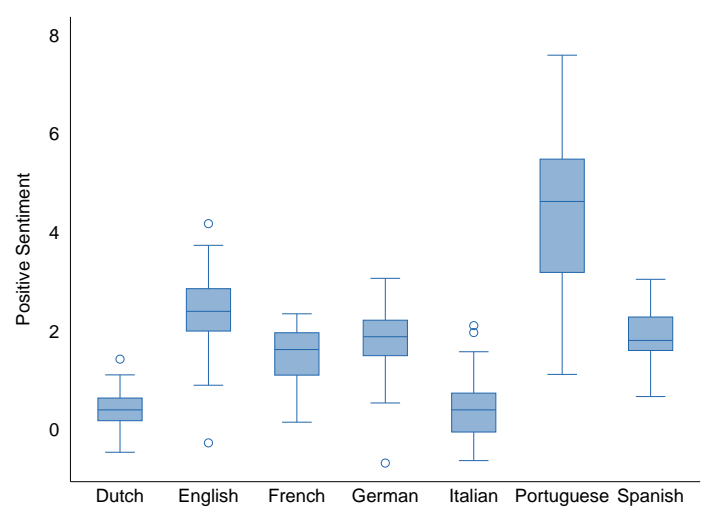

(c) Positive Sentiment

\section{Independent Variables}

To test our hypotheses, we created two variables capturing a party's incumbency status. Incumbent Party is a dichotomous variable that equals 1 when the party is in government, 0 otherwise. Incumbent Party $\times$ Prime Ministerial Party is another dichotomous variable that equals 1 when the party is the prime ministerial party, 0 otherwise. ${ }^{12}$ Information on a party's incumbency status comes from Glasgow, Golder and Golder (2011).

We created two variables to evaluate our Extreme Ideology Hypothesis. Left-Right captures a party's position on a 0-10 left-right scale as identified by country experts (Döring and Manow, 2015). Left-Right ${ }^{2}$ is a quadratic term designed to test the conditional claim that extremist parties use less positive sentiment

\footnotetext{
${ }^{12}$ We do not need to include a dichotomous variable, Prime Ministerial Party, in our empirical analysis even though it is a constitutive element of our interaction variable. This is because its inclusion leads to perfect multicollinearity given that Prime Ministerial Party is only equal to 1 when the party is also an incumbent party (Brambor, Clark and Golder, 2006, 70, note 8).
} 
than moderate parties. As an alternative strategy for evaluating our hypothesis, we created a third variable, Extremist Party, based on a party's 'family'. Extremist Party is a dichotomous variable that equals 1 if a party belongs to a party family on the extreme left (communist) or extreme right (far right), 0 otherwise. ${ }^{13}$ Data for this come from the Parliaments and Governments Database (Döring and Manow, 2015).

We also created measures of economic performance. We focus on unemployment, inflation, and growth, because the economic voting literature singles these indicators out as being "related to changes in support for the government in many countries" (Powell and Whitten, 1993, 392). Unemployment is the unemployment rate (International Monetary Fund, 2015), Inflation is the inflation rate (World Bank, 2012), and Growth is the percentage growth in real GDP expenditures from the Penn World Tables 9.0 (Feenstra, Inklaar and Timmer, 2015). We lag these variables by a year to ensure they reflect the economic conditions at a time prior to when the parties write their manifestos. We also create interactions between each of them and Incumbent Party to test the conditionality of the Conditional Economic Performance Hypothesis and the Conditional Incumbent Party Hypothesis.

\section{Model Specification and Results}

We test our hypotheses using ordinary least squares with bootstrap standard errors clustered by election. We cluster the standard errors to take account of the fact that the content and language used in manifestos are unlikely to be independent in a given election. We employ bootstrap standard errors because the literature is unclear as to when the number of clusters is sufficiently large to justify the asymptotic assumptions underlying traditional cluster-robust standard errors (Esarey and Menger, 2018; Wooldridge, 2003, 135). ${ }^{14}$ We also include language fixed effects to take account of the fact that users of different languages differ in their proclivity to employ positive and negative emotive words. ${ }^{15}$

The results of eleven different models are shown in Table 2. The first two columns focus on the relationship between positive sentiment and incumbency status. The next two columns add our indicators of party position. The following three columns add our economic indicators. The last four columns examine the conditional relationship between incumbency status and our three economic indicators, first separately and then together. Our models are specified so that the coefficients on the constant terms indicate the average

\footnotetext{
${ }^{13}$ Our results remain robust if we also classify Green parties as extreme left.

${ }^{14}$ Results are stronger with traditional cluster-robust standard errors; they are also robust to not clustering the standard errors.

${ }^{15}$ As Online Appendix C indicates, our results are qualitatively similar if we employ country fixed effects.
} 


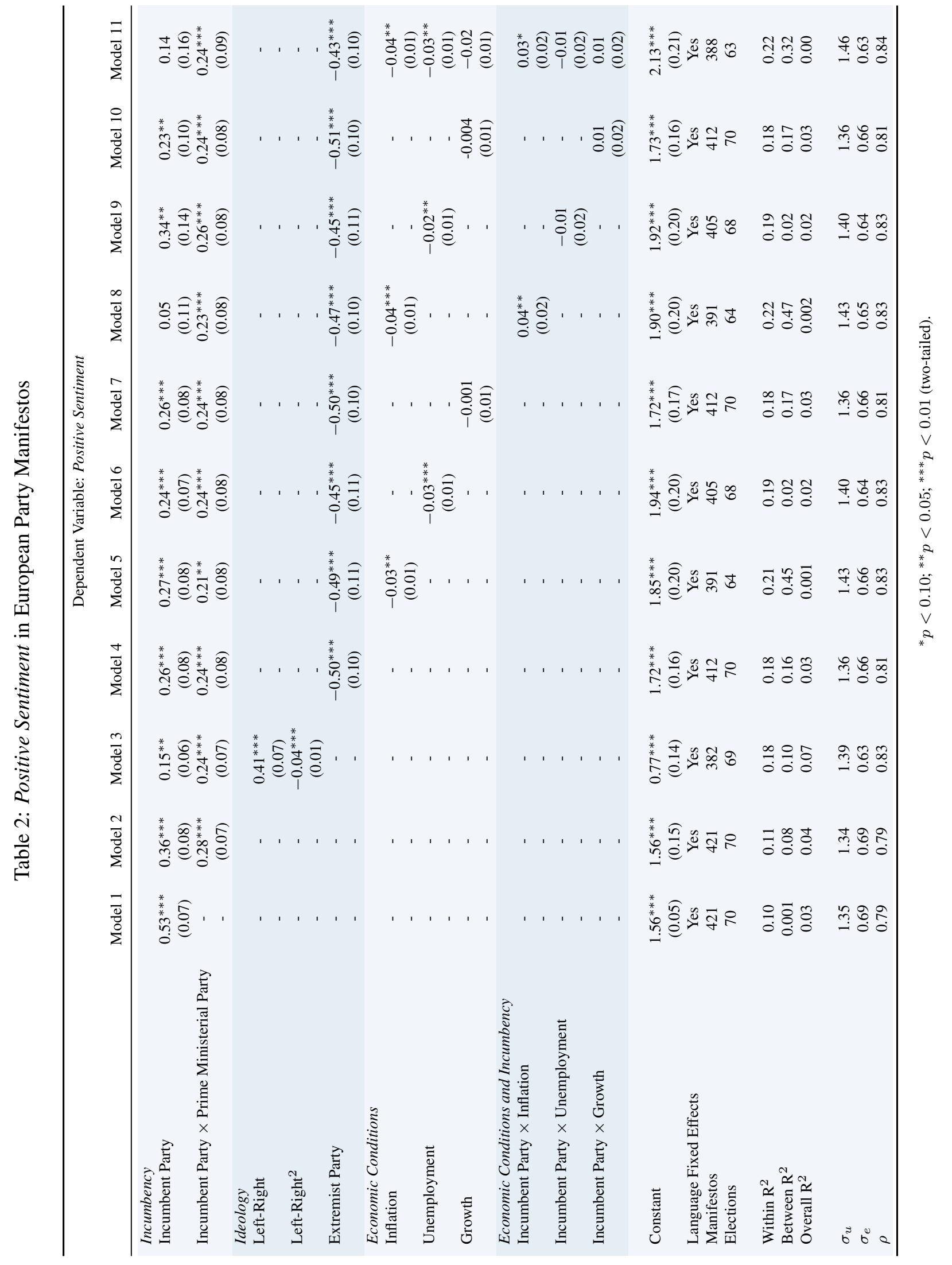

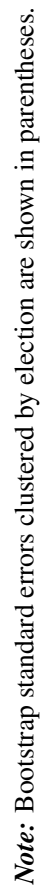


language fixed effect. ${ }^{16} \sigma_{u}$ indicates the standard deviation for the language fixed effects, while $\sigma_{e}$ indicates the standard deviation for the idiosyncratic error terms associated with the manifestos. The intraclass correlation coefficient, $\rho$, captures the proportion of the total variance attributable to the language fixed effects. In line with the information in Figure 2 showing the strong impact that language has on the proclivity to use emotive words, the values of $\rho$ reported in Table $2(0.79-0.84)$ indicate that the language fixed effects play a large role in explaining the variation we observe in the use of positive sentiment.

As predicted by the Incumbent Party Hypothesis, Model 1 shows that incumbent parties use significantly more positive emotive language than opposition parties. This is indicated by the positive and significant coefficient on Incumbent Party. ${ }^{17}$ The effect of incumbency is substantively large — positive sentiment is $34 \%$ [24.6\%, $44.9 \%$ ] higher for incumbent parties than opposition parties. $95 \%$ two-tailed confidence intervals are shown in parentheses. Importantly, the positive and statistically significant coefficient on Incumbent Party is robust to the use of party fixed effects. This is particularly compelling evidence in support of our Incumbent Party Hypothesis as it indicates that the same party alters its use of positive sentiment in the predicted manner when it moves in and out of office. ${ }^{18}$ Our results here are in line with those reported by Rheault et al. (2016) in their analysis of emotional polarity in British parliamentary debates. As predicted by the Prime Ministerial Party Hypothesis, the results in Model 2 indicate that prime ministerial parties adopt even higher levels of positive sentiment in their manifestos than their coalition partners. This is indicated by the positive and significant coefficient on Incumbent $\times$ Prime Ministerial Party.

Figure 3 provides a graphical summary of our incumbency results. It shows how the predicted level of Positive Sentiment changes with a party's incumbency status based on the results in Model 2. The solid blue lines represent two-tailed 95\% confidence intervals. Non-prime ministerial incumbent parties exhibit $23 \%$ $[12.9 \%, 34.5 \%]$ more positive sentiment than opposition parties. Prime ministerial incumbent parties exhibit $41 \%$ [30\%, 53.8\%] more positive sentiment than opposition parties. And prime ministerial incumbent parties exhibit $18 \%$ [8.8\%,27.5\%] more positive sentiment than non-prime ministerial incumbent parties. ${ }^{19}$

\footnotetext{
${ }^{16}$ For those who are interested in the individual estimates of the language fixed effects, see Online Appendix C.

${ }^{17}$ Incumbents arguably have weaker incentives to frame the world in a positive light when there is low clarity of responsibility (Powell and Whitten, 1993). However, there is only limited support for this conjecture in our data. When we add an interaction term between Incumbent Party and a dichotomous variable for coalition government, we find that the coefficient on the interaction term is negative, indicating that incumbent parties in coalition governments do use less positive sentiment than those in single-party governments. However, the coefficient on the interaction term is not statistically significant.

${ }^{18}$ To feasibly use party fixed effects, we need sufficient within-party variation in our covariates over time. Although limited, we have just enough variation on a party's incumbency status to be able to employ party fixed effects for the specification shown in Model 1. Of the 108 parties for which we have manifestos, 32 exhibit variation in their incumbency status, with 22 having been incumbents more than once. Unfortunately, we do not have sufficient within-party variation (or indeed any variation for covariates
} 
Figure 3: Positive Sentiment and a Party's Incumbency Status

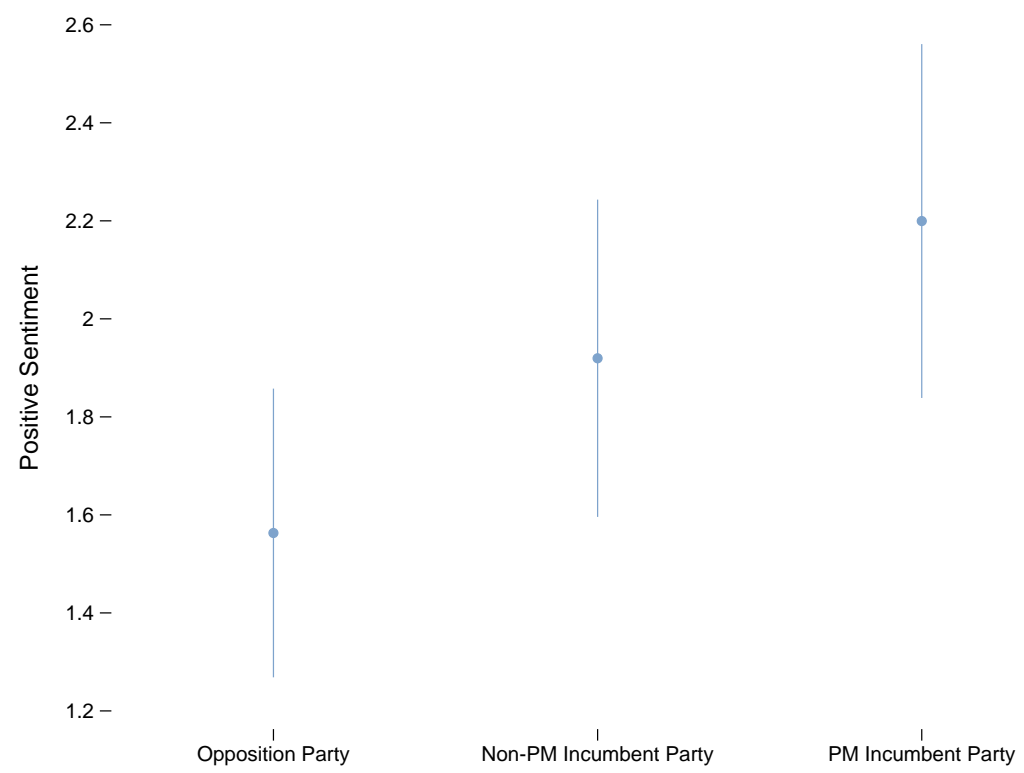

Note: Figure 3 plots the predicted level of Positive Sentiment conditional on incumbency status based on Model 2 in Table 2. The lines represent two-tailed $95 \%$ confidence intervals.

These results are qualitatively similar across all the models in Table $2 .{ }^{20}$ Overall, our results with respect to incumbency are strongly supportive of our theoretical argument and are consistent with the idea that parties think and act strategically, not only about the substantive content of their party manifestos, but also about the emotive language they use to convey that content. Our results speak directly to empirical studies finding that voters hold prime ministerial parties more responsible for the state of the world than their coalition partners (Duch and Stevenson, 2008, 2013; Debus, Stegmaier and Tosun, 2014; Duch, Przepiorka and Stevenson, 2015). This is because they suggest that prime ministerial parties are aware of this voter behavior and alter their campaign strategy in response by adopting more positive sentiment than their coalition partners.

As predicted by the Extreme Ideology Hypothesis, ideologically extreme parties use less positive sentiment than moderate parties. This is indicated by the positive and significant coefficient on Left-Right and the negative and significant coefficient on Left-Right ${ }^{2}$ in Model 3. Together these coefficients indicate such as Extremist Party) to feasibly employ party fixed effects in our other models.

${ }^{19}$ The confidence intervals in Figure 3 overlap slightly. However, overlapping confidence intervals are not necessarily evidence that the differences between point estimates are statistically insignificant (Schenker and Gentleman, 2001). Indeed, we know that these differences are significant as the coefficients on Incumbent Party and Incumbent Party $\times$ Prime Ministerial Party in Model 2 are both statistically significant $(p<0.001)$.

${ }^{20}$ Not too much should be read into the statistically insignificant coefficients on Incumbent Party in Models 8 and 11 , as these coefficients capture the effect of being a non-prime ministerial incumbent party when inflation (as well as unemployment and growth) is zero. 
that positive sentiment first rises and then falls as a party's position moves across the policy space. This is graphically illustrated in Figure 4. The solid black line indicates the predicted level of positive sentiment exhibited by opposition parties based on Model $3 .{ }^{21}$ The black vertical axis on the left indicates the predicted value of Positive Sentiment. The gray vertical axis on the right pertains to the histogram and indicates the percentage of observations at different values of Left-Right. Positive sentiment is maximized when a party's policy position is at 5.45 and declines sharply as a party's position moves towards either the extreme left or right. This is exactly in line with our theoretical story.

Figure 4: Positive Sentiment and a Party's Left-Right Policy Position

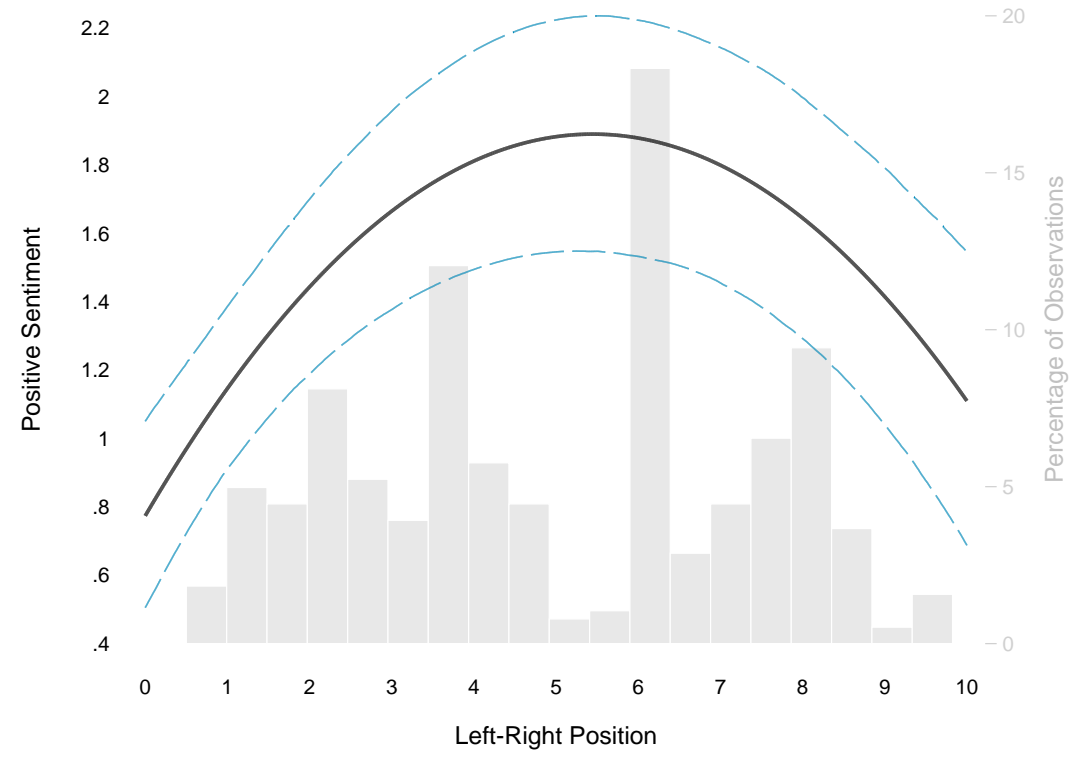

Note: Figure 4 plots the predicted level of Positive Sentiment for opposition parties across the left-right policy space based on Model 3 in Table 2. The dashed lines represent two-tailed $95 \%$ confidence intervals.

Further support for the Extreme Ideology Hypothesis comes from Model 4. As predicted, the coefficient on Extremist Party is negative and significant, indicating that ideologically extreme parties exhibit less positive sentiment than moderate parties. Again, this effect is substantively large. For example, Model 4 indicates that extremist opposition parties employ $29.3 \%$ [18.6\%, 40\%] less positive sentiment than moderate opposition parties. Our results with respect to how a party's policy position influences its level of positive sentiment are qualitatively similar across all the models in Table $2 .^{22}$

\footnotetext{
${ }^{21}$ The shape of this black line is the same for incumbent parties. The only difference is that the line would be shifted up to reflect the higher level of positive sentiment exhibited by incumbent parties, something indicated by the positive and statistically significant coefficients on Incumbent Party and Incumbent Party $\times$ Prime Ministerial Party in Model 3.

${ }^{22}$ To maximize our sample size when evaluating our Extreme Ideology Hypothesis, we focus on the dichotomous Extremist Party
} 
In line with the Economic Performance Hypothesis, parties adopt less positive sentiment when the economy is performing poorly with respect to inflation and unemployment. This is indicated by the negative and significant coefficients on Inflation in Model 5 and Unemployment in Model 6. These particular results suggest that campaign sentiment does vary in line with objective economic conditions, just as the standard economic voting framework would lead us to expect. There is no evidence, however, that positive sentiment varies with economic growth. This is indicated by the substantively small and insignificant coefficient on Growth in Model 7. Interestingly, our results with respect to economic conditions are entirely consistent with previous research showing that unemployment and inflation have a significantly stronger impact on the emotional polarity of British parliamentary debates than economic growth (Rheault et al., 2016). They are also consistent with research showing that the extent to which parties emphasize economic issues in their manifestos varies systematically with inflation and unemployment but not with economic growth (Williams, Seki and Whitten, 2016). Combining these results suggests that objective economic conditions (inflation, unemployment) influence not only how much space parties give to economic issues in their manifestos but also the emotive content of the language that parties use to convey their political messages.

Does the effect of objective economic conditions vary with incumbency status as the Conditional Economic Performance Hypothesis predicts? Strong support for this exists for inflation. This is indicated by the negative and significant coefficient on Inflation and the positive and significant coefficient on Incumbent Party $\times$ Inflation in Model 8. To evaluate the conditional effect of economic performance and incumbency status in more detail, Figure 5(a) plots the effect of a one standard deviation increase in inflation on Positive Sentiment for opposition and incumbent parties. Inflation has a strong negative and significant effect on positive sentiment for opposition parties. Although the effect of inflation remains negative for incumbent parties, it is much smaller and is no longer significant. This is consistent with our claim that incumbent parties use positive campaign sentiment to frame poor economic performance in as good a light as they can whereas opposition parties try to frame it in as bad a light as they can.

There is no support for the Conditional Economic Performance Hypothesis when we focus on unemployment. The results in Model 8 indicate that unemployment always reduces positive sentiment. However, the magnitude of this effect does not vary with incumbency status. This is indicated by the negative and significant coefficient on Unemployment and the insignificant coefficient on Incumbent Party $\times$ Unemployment. As Figure 5(b) visually demonstrates, a one standard deviation increase in unemployment has a similarly variable in Models 4-11. However, our inferences are robust to substituting in our Left-Right and Left-Right ${ }^{2}$ variables instead. 
Figure 5: The Effect of Objective Economic Indicators on Positive Sentiment conditional on Incumbency Status

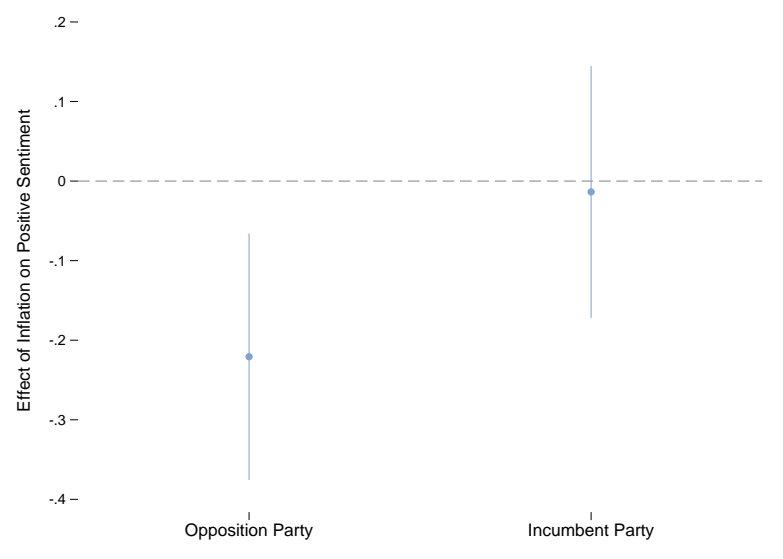

(a) Inflation

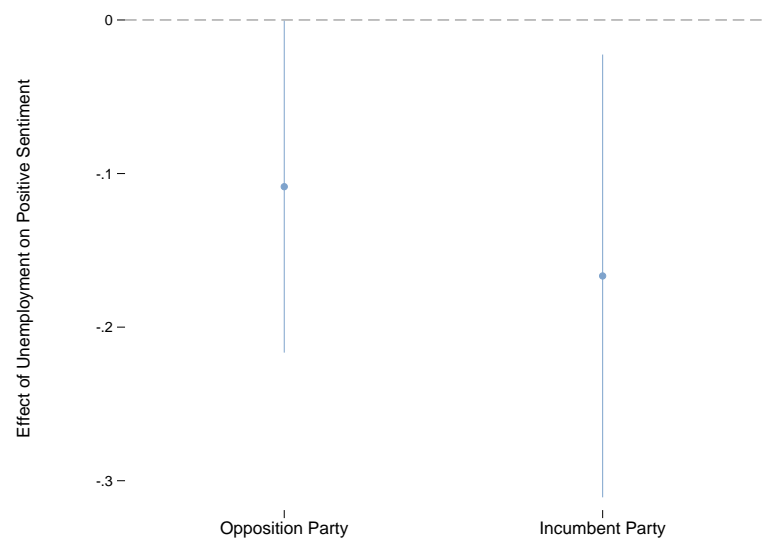

(b) Unemployment

Note: Panel (a) shows the effect of a one standard deviation increase in inflation on Positive Sentiment for opposition and incumbent parties based on Model 8 in Table 2. Panel (b) shows the effect of a one standard deviation increase in unemployment on Positive Sentiment for opposition and incumbent parties based on Model 9. The lines represent two-tailed $95 \%$ confidence intervals. The coefficient on Incumbent Party $\times$ Inflation is 0.04 (0.02), while the coefficient on Incumbent Party $\times$ Unemployment is $-0.01(0.02)$; standard errors are shown in parentheses.

sized negative effect on positive sentiment for both opposition and incumbent parties — the two confidence intervals overlap almost entirely. As Model 11 indicates, our results with respect to inflation and unemployment are robust to including all three of our measures of objective economic performance in the same specification. ${ }^{23}$ That we obtain slightly different conditional results with respect to inflation as opposed to unemployment suggests that parties may feel they can use emotive language to frame some economic conditions more than others. One interpretation is that incumbent parties feel free to ignore inflation when it comes to the emotive content of their campaign messages but not unemployment.

Our last hypothesis, the Conditional Incumbent Party Hypothesis, has to do with how the effect of incumbency status varies with objective economic conditions. Recall that we expect the positive effect of incumbency on campaign sentiment to be greater when the economy is performing poorly. We obtain strong support for this when we focus on inflation. This is indicated by the positive and significant coefficient on Incumbent Party $\times$ Inflation in Model 8. In Figure 6, we plot the effect of being the incumbent prime ministerial party on positive sentiment across the observed range of inflation. As predicted, this marginal effect, which is always positive and significant, grows in magnitude with higher rates of inflation. We do not ob-

\footnotetext{
${ }^{23}$ We do not examine the conditional effect of economic growth in Figure 5. Consistent with our previous discussion, there is no evidence that growth ever has a significant effect on positive sentiment. This is indicated by the insignificant coefficients on Growth and Incumbent Party $\times$ Growth in Models 10 and 11 .
} 
Figure 6: The Effect of Incumbency Status on Positive Sentiment conditional on Inflation

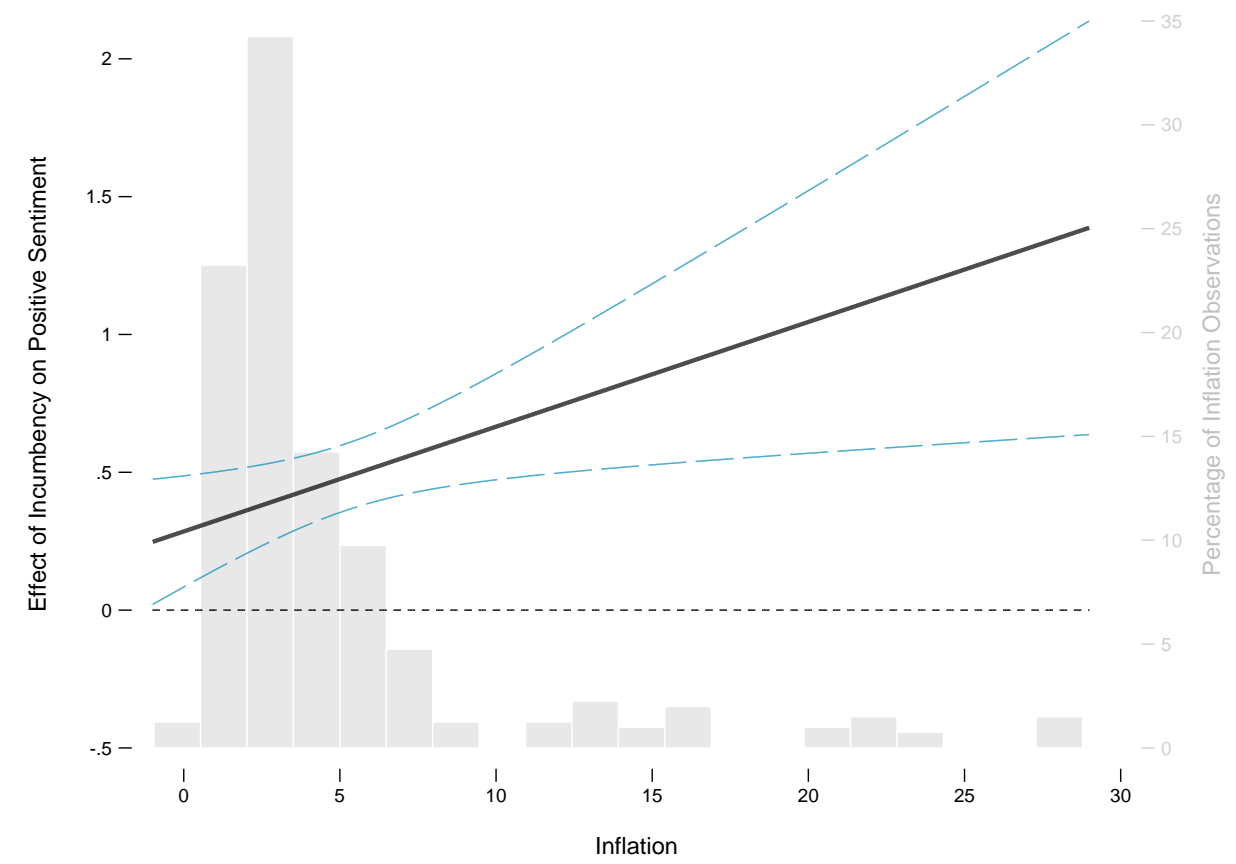

Note: Figure 6 shows the effect of being the incumbent prime ministerial party on Positive Sentiment across the observed range of inflation based on Model 8 in Table 2. The dashed lines represent two-tailed 95\% confidence intervals.

tain such strong support for the Conditional Incumbent Party Hypothesis when we focus on unemployment. While we find that incumbency status always increases positive campaign sentiment as predicted, we do not find that the magnitude of this effect increases with unemployment. This is indicated by the insignificant coefficient on Incumbent Party $\times$ Unemployment in Model 9.

\section{Conclusion}

Scholars have recently shown that campaigns can engender different types of emotion and thereby shape voter behavior and perceptions of the world in predictable ways. An implication of this is that political parties have incentives to be strategic not only about the substantive content of their campaigns but also about the kind of sentiment they use to convey that content. Some parties should adopt sentiment that frames the world in a positive light, whereas others should adopt sentiment that frames it in a negative light.

Building on the logic underpinning models of retrospective voting, we employed a novel dataset on the emotive language used in over 400 European party manifestos to examine how the level of positive 
sentiment exhibited by political parties depends on their incumbency status, policy position, and objective economic conditions. As predicted, incumbent parties, especially prime ministerial parties, exhibit greater positive sentiment than opposition parties. Also in line with our expectations, we found that ideologically extreme parties adopt much less positive sentiment than moderate parties, and that all parties adopt significantly less positive sentiment when objective economic conditions are poor. These results suggest that parties are indeed strategic about the type of emotive language they employ in their manifestos. Our case study of the 2013 German elections in Online Appendix D provides evidence that parties are also strategic with respect to their use of emotive language in other types of campaign messages.

Our findings have important implications for the study of election campaigns and party strategies. First, scholars have conceptualized campaigns along two primary dimensions. The campaign content dimension captures whether parties compete on policy or valence. The campaign focus dimension captures whether parties focus their campaigns on themselves or their opponents. We have argued that campaign sentiment, which captures the emotive content of campaigns, represents a conceptually and empirically distinct third dimension. Campaigns are about what parties say, who they say it about, and how they say it. In effect, political parties have a larger arsenal of campaign strategies available to them than is assumed in much of the existing literature. While recent studies have demonstrated that campaign sentiment can influence voter behavior in predictable ways, our analysis is the first to present cross-national evidence that political parties deploy campaign sentiment in a strategic manner in multiparty contexts.

Second, our argument provides a possible explanation for why people hold different perceptions of objective economic conditions and why these differing perceptions are frequently tied to an individual's partisan identity (MacKuen, Erikson and Stimson, 1989; Duch, Palmer and Anderson, 2000; Anderson, 2007; Enns, Kellstedt and McAvoy, 2012). While our findings suggest that parties use campaign sentiment to strategically frame the state of the world, they are not necessarily inconsistent with research showing that voters generally respond to objective economic reality (Lewis-Beck, Nadeau and Elias, 2008; Nadeau, Lewis-Beck and Éric Bélanger, 2013; Lewis-Beck, Martini and Kiewiet, 2013). As Gelman and King (1993) note, high-information and balanced electoral campaigns between parties with competing strategic interests can produce 'enlightened preferences' on the part of voters.

Although the strategic use of campaign sentiment helps to explain the divergent perceptions of the economy among voters, our findings are encouraging in that they also indicate that election campaigns are not completely devoid of information. That all parties use less positive sentiment when the economy 
is performing poorly suggests that objective economic conditions constrain the strategic use of campaign sentiment. In effect, campaigns retain some of their information content despite the incentives parties have to manipulate the emotional responses of voters. Viewed in this light, the advent of 'fake news' and campaigns of deliberate misinformation are a cause for concern, in that these developments may serve to weaken the constraints offered by objective economic conditions and thereby provide parties with more room to engage in the strategic manipulation of voter emotions.

Third, scholars typically examine campaign strategy at the party- or candidate-level. Several studies, for example, claim that trailing candidates are more likely to adopt 'attack campaigns' than front-runners (Skaperdas and Grofman, 1995). Relatively little attention is paid to how the broader electoral context in which parties compete constrains their strategic choices (Vavreck, 2009). Our finding that objective economic conditions constrain the strategic use of campaign sentiment suggests that an election's macroeconomic context affects the choices parties make with respect to their campaign strategy (Parker-Stephen, 2013; Pardos-Prado and Sagarzazu, 2016). As such, studies of campaign strategy that cover multiple elections should pay greater attention to the context in which their elections take place.

Fourth, the strategic use of campaign sentiment by political parties has implications for democratic accountability. If voters are susceptible to the manipulation of campaign sentiment, then the link between government performance and the electoral success of incumbent parties is weakened. Whether this ultimately helps or harms the reelection prospects of government parties is, however, unclear. As we have argued, incumbent parties have an incentive to employ positive campaign sentiment to portray the world in the best possible light. To the extent that scholars have empirically examined the role of emotions in politics, most have focused on negative sentiment (Utych, 2018) and the effectiveness of messages that trigger fear or anger (Merolla and Zechmeister, 2009). We know much less about the effectiveness of messages designed to convey positive sentiment. As a result, we need more research to assess whether, or when, the use of campaign sentiment disadvantages incumbent parties.

We still know relatively little about the strategic use of emotive content in election campaigns. Here we have focused on the use of broad emotive categories — positive and negative sentiment. Future research might fruitfully focus on whether parties are strategic with respect to their use of more specific emotions such as fear, anger, or enthusiasm. Alternatively, scholars could look at whether the overall amount of emotive content in election campaigns has changed over time (Rheault et al., 2016). Do some parties, such as populist parties or those with charismatic leaders, use more emotion in their campaigns than others? How 
do parties respond to the emotive content in their rivals' campaigns? Does the emotive content of a party's current election campaign depend on how that party performed in the previous election? To a large extent, the field of research looking at the strategic use of campaign sentiment is wide open. 


\section{References}

Adams, James F. 2001. Party Competition and Responsible Party Government: A Theory of Spatial Competition Based Upon Insights from Behavioral Voting Research. Ann Arbor, MI: Michigan University Press.

Adams, James F., Ethan Scheiner and Jed Kawasumi. 2016. "Running on character? Running on policy? An analysis of Japanese candidates' campaign platforms." Electoral Studies 44:277-283.

Adams, James F., Samuel Merrill and Bernard Grofman. 2005. A Unified Theory of Party Competition: A Cross-National Analysis Integrating Spatial and Behavioral Factors. New York: Cambridge University Press.

Adams, James, Lawrence Ezrow and Zeynep Somer-Topcu. 2011. "Is anybody listening? Evidence that voters do not respond to European parties' policy statement during elections." American Journal of Political Science 55(2):370-382.

Alpers, George W., Andrew J. Winzelberg, Catherine Classen, Heidi Roberts, Parvati Dev, Cheryl Koopman and C. Barr Taylor. 2005. "Evaluation of computerized text analysis in an Internet breast cancer support group." Computers in Human Behavior 21(2):361-376.

Anderson, Christopher. 2007. "The end of economic voting? Contingency dilemmas and the limits of democratic accountability.” Annual Review of Political Science 10:271-296.

Ansolabehere, Stephen. 2006. The paradox of minimal effects. In Capturing Campaign Effects, ed. Henry E. Brady and Richard Johnston. Ann Arbor: University of Michigan Press pp. 29-44.

Ansolabehere, Stephen and James M. Snyder. 2000. "Valence politics and equilibrium in spatial election models." Public Choice 103:327-336.

Benoit, Kenneth. 2017. quanteda: Quantitative Analysis of Textual Data. R package version 0.99.9001.

Benoit, Kenneth, Thomas Bräuninger and Marc Debus. 2009. "Challenges for estimating policy preferences: Announcing an open access archive of political documents." German Politics 18(3):441-454.

Berry, William D., Matt Golder and Daniel Milton. 2012. "Improving tests of theories positing interaction." Journal of Politics 74(3):653-671.

Brader, Ted. 2005. "Striking a responsive chord: How political ads motivate and persuade voters by appealing to emotions." American Journal of Political Science 49(2):388-405.

Brader, Ted. 2006. Campaigning for Hearts and Minds: How Emotional Appeals in Political Ads Work. New York: Cambridge University Press.

Brader, Ted and George E. Marcus. 2013. Emotions and Political Psychology. In The Oxford Handbook of Political Psychology, ed. Leonie Huddy, David O. Sears and Jack S. Levy. Oxford: Oxford University Press pp. 165-204.

Brambor, Thomas, William Roberts Clark and Matt Golder. 2006. "Understanding interaction models: Improving empirical analyses." Political Analysis 14(1):63-82.

Breeze, Ruth. 2011. "Variations on a theme: Party manifesto discourses in the UK 2010 election." Culture, Language and Representation 9:9-30. 
Bryan, Amanda C. and Eve M. Ringsmuth. 2016. "Jeremiad or weapon of words? The power of emotive language in Supreme Court dissents." Journal of Law and Courts 4(1):159-185.

Budge, Ian and Dennis J. Farlie. 1983a. Explaining and Predicting Elections. London: George Allen and Unwin.

Budge, Ian and Dennis J. Farlie. 1983b. Party competition - Selective emphasis or direct confrontation. In Western European Party Systems, ed. Hans Daalder and Peter Mair. London: Sage.

Budge, Ian, Hans-Dieter Klingemann, Andrea Volkens, Judith Bara and Eric Tanenbaum. 2001. Mapping Policy Preferences. Estimates for Parties, Electors, and Governments 1945-1998. New York: Oxford University Press.

Chong, Dennis and James N. Druckman. 2007. "Framing theory." Annual Review of Political Science 10:103-126.

Christakis, Nicholas and James H. Fowler. 2009. Connected: The Surprising Power of our Social Networks and How They Shape our Lives. New York: Little, Brown and Company.

Conover, Pamela Johnston and Stanley Feldman. 1986. "Emotional reactions to the economy: I'm mad as hell and I'm not going to take it anymore." American Journal of Political Science 30(1):50-78.

Corley, Pamela C. and Justin Wedeking. 2014. "The (Dis)advantage of certainty: The importance of certainty in language." Law \& Society Review 48(1):35-62.

Dathan, Matt. 2015. “General election: Why manifestos aren't worth the paper they're written on but the one reason why they matter more than ever to politicians." The Independent April 13.

Däubler, Thomas. 2012a. "The preparation and use of election manifestos: Learning from the Irish case." Irish Political Studies 27(1):51-70.

Däubler, Thomas. 2012b. “Wie entstehen Wahlprogramme?” Zeitschrift für Politikwissenschaft 22(3):333365.

Debus, Marc, Mary Stegmaier and Jale Tosun. 2014. "Economic voting under coalition governments: Evidence from Germany." Political Science Research and Methods 2(1):49-67.

Dolezal, Martin, Laurenz Ennser-Jedenastik, Wolfgang C. Müller and Anna Katharina Winkler. 2012. "The life-cycle of party manifestos: The Austrian case.” West European Politics 35(4):869-895.

Dolezal, Martin, Laurenz Ennser-Jedenastik, Wolfgang C. Müller and Anna Katharina Winkler. 2014. "How parties compete for votes: A test of salience theory." European Journal of Political Research 53:57-76.

Döring, Holger and Philip Manow. 2015. "Parliaments and governments database (ParlGov): Information on parties, elections, and cabinets in modern democracies.".

D’Ottavio, Gabriele and Thomas Saalfeld, eds. 2016. Germany After the 2013 Elections: Breaking the Mould of Post-Unification Politics. New York: Routledge.

Downs, Anthony. 1957. An Economic Theory of Democracy. New York: Harper and Row.

Duch, Raymond M., Harvey D. Palmer and Christopher Anderson. 2000. "Heterogeneity in perceptions of national economic conditions." American Journal of Political Science 44:635-652. 
Duch, Raymond M. and Randolph T. Stevenson. 2008. The Economic Vote: How Political and Economic Institutions Condition Election Results. New York: Cambridge University Press.

Duch, Raymond and Randolph T. Stevenson. 2013. "Voter perceptions of agenda power and attribution of responsibility for economic performance." Electoral Studies 32:512-516.

Duch, Raymond, Wojtek Przepiorka and Randolph T. Stevenson. 2015. "Responsibility attribution for collective decison makers." American Journal of Political Science 59(2):372-389.

Edelman, Murray. 1964. The Symbolic Use of Politics. Urbana: University of Illinois Press.

Edelman, Murray. 1977. Political Language: Words that Succeed and Policies that Fail. London: Academic Press.

Edelman, Murray. 1985. "Political language and political reality." PS: Political Science and Politics 18(1):10-19.

Elmelund-Præstekær, Christian. 2008. "Negative campaigning in a multiparty system." Representation 44(1):27-39.

Elmelund-Præstekær, Christian. 2010. "Beyond American negativity: Toward a general understanding of the determinants of negative campaigning." European Political Science Review 2(1):137-156.

Enns, Peter K., Paul M. Kellstedt and Gregroy E. McAvoy. 2012. "The consequences of partisanship in economic perceptions." Public Opinion Quarterly 76(2):287-310.

Esarey, Justin and Andrew Menger. 2018. "Practical and effective approaches to dealing with clustered data." Political Science Research and Methods .

Feenstra, Robert C., Robert Inklaar and Marcel P. Timmer. 2015. "The next generation of the Penn World Table." American Economic Review 105(10):3150-3182.

Foucault, Michel. 1972. The Order of Things: An Archaelogy of the Human Sciences. London: Tavistock.

Geer, John G. 2006. In Defense of Negativity: Attack Ads in Presidential Campaigns. Chicago: University of Chicago Press.

Gelman, Andrew and Gary King. 1993. "Why are American presidential election campaign polls so variable when votes are so predictable?" British Journal of Political Science 23:409-451.

Gibson, Rachel. 2004. "Web campaigning from a global perspective.” Asia-Pacific Review 11(1):95-126.

Gibson, Rachel and Andrea Römmele. 2009. "Measuring the professionalization of political campaigning." Party Politics 15(3):265-293.

Glasgow, Garrett, Matt Golder and Sona N. Golder. 2011. "Who "wins"? Determining the party of the prime minister." American Journal of Political Science 55(4):937-954.

Golder, Matt. 2016. “Far right parties in Europe.” Annual Review of Political Science 19:477-497.

Green, Jane and Sara B. Hobolt. 2008. "Owning the issue agenda: Party strategies and vote choices in British elections.” Electoral Studies 27(3):460-476.

Hansen, Kasper M. and Rasmus Tue Pedersen. 2008. "Negative campaigning in a multiparty system." Scandinavian Political Studies 31(4):408-427. 
Hart, Roderick P., Jay P. Childers and Colene J. Lind. 2013. Political Tone: How Leaders Talk and Why. Chicago: University of Chicago.

Healy, Patrick and Maggie Habermandec. 2015. "95,000 words, many of them ominous, from Donald Trump's tongue." New York Times, December 5.

Hipt, Manfred Opp de. 1990. "Mental pictures of the state in West German party platforms: A research note." European Journal of Political Research 18:207-219.

Holtz-Bacha, Christina and Marion R. Just, eds. 2017. Routledge Handbook of Political Advertising. London: Routledge.

Huddy, Leonie and Anna H. Gunnthorsdottir. 2000. "The persuasive effects of emotive visual imagery: Superficial manipulation or the product of passionate reason?" Political Psychology 21(4):745-778.

International Monetary Fund. 2015. "World economic outlook database.".

Janda, Kenneth, Robert Harmel, Christine Edens and Patricia Goff. 1995. "Changes in party identity: Evidence from party manifestos." Party Politics 1(2):171-196.

Kenny, Christopher. 1998. "The behavioral consequences of political discussion: Another look at discussant effects on vote choice." Journal of Politics 60(1):231-244.

King, Gary, Ori Rosen, Martin Tanner and Alexander Wagner. 2013. "Ordinary economic voting behavior in the extraordinary election of Adolf Hitler.” Journal of Economic History 68(4):951-996.

Kosmidis, Spyros, Sara B. Hobolt, Eamonn Molloy and Stephen Whitefield. Forthcoming. "Party competition and emotive rhetoric." Comparative Political Studies .

Lakoff, George. 2016. “Understanding Trump’s use of language.” Blog post, April 19.

Lau, Richard R. and Gerald M. Pomper. 2002. Negative Campaigning: An Analysis of U.S. Senate Elections. Oxford: Rowman and Littlefield.

Lau, Richard R and Ivy Brown Rovner. 2009. "Negative campaigning." Annual Review of Political Science 12:285-306.

Lewis-Beck, Michael, Nicholas F. Martini and D. Roderick Kiewiet. 2013. "The nature of economic perceptions in mass publics." Electoral Studies 32:524-528.

Lewis-Beck, Michael S. and Mary Stegmaier. 2000. "Economic determinants of electoral outcomes.” Annual Review of Political Science 3:183-219.

Lewis-Beck, Michael S., Richard Nadeau and Angelo Elias. 2008. "Economics, party, and the vote: Causality issues and panel data." American Journal of Political Science 52(1):84-95.

MacKuen, Michael B., Robert S. Erikson and James A. Stimson. 1989. "Macropartisanship.” American Political Science Review 83:1125-1142.

Marcus, George E. 2000. “Emotions in politics.” Annual Review of Political Science 3(1):221-250.

Marcus, George E., W. Russell Neuman and Michael MacKuen. 2000. Affective Intelligence and Political Judgment. New York: Cambridge University Press. 
Merolla, Jennifer L. and Elizabeth J. Zechmeister. 2009. Democracy at Risk: How Terrorist Threats Affect the Public. Chicago: University of Chicago Press.

Mudde, Cas. 2007. Populist Radical Right Parties in Europe. New York: Cambridge University Press.

Nadeau, Richard, Michael S. Lewis-Beck and Éric Bélanger. 2013. "Economics and elections revisited." Comparative Political Studies 46(5):551-573.

Norpoth, Helmut, Michael Lewis-Beck and Jean-Dominique Lafay. 1991. Economics and Politics: The Calculus of Support. Ann Arbor: University of Michigan Press.

Norpoth, Helmut and Thomas Gschwend. 2010. "The chancellor model: Forecasting German elections." International Journal of Forecasting 26(1):42-53.

Nyhan, Brendan and Jason Reifler. 2015. "The effect of fact-checking on elites: A field experiment on U.S. state legislators.” American Journal of Political Science 59(3):628-640.

Owens, Ryan J. and Justin P. Wedeking. 2011. "Justices and legal clarity: Analyzing the complexity of US supreme court opinions." Law and Society Review 45(4):1027-1061.

Owens, Ryan J. and Justin P. Wedeking. 2012. "Predicting drift on politically insulated institutions: A study of ideological drift on the United States supreme court." Journal of Politics 74(2):487-500.

Pardos-Prado, Sergi and Iñaki Sagarzazu. 2016. "The political conditioning of subjective economic evaluations: The role of party discourse." British Journal of Political Science 46(4):799-823.

Parker-Stephen, Evan. 2013. "Tides of disagreement: How reality facilitates (and inhibits) partisan public opinion.” Journal of Politics 75(4):1077-1088.

Pennebaker, James W. 1993. "Putting stress into words: Health, linguistic, and therapeutic implications." Behaviour Research and Therapy 31(6):539-548.

Pennebaker, James W., Cindy K. Chung, Molly Ireland, Amy Gonzales and Roger J. Booth. 2007. "The development and psychometric properties of LIWC2007. Austin, TX: [LIWC manual].”.

Pennebaker, James W. and Martha E. Francis. 1996. "Cognitive, emotional, and language processes in disclosure." Cognition and Emotion 10(6):601-626.

Pennebaker, James W., Roger J. Booth and Martha E. Francis. 2007. "Linguistic inquiry and word count: LIWC [Computer software]. Austin, TX: [Operator's manual].".

Powell, G. Bingham and Guy D. Whitten. 1993. "A cross-national analysis of economic voting: Taking account of the political context." American Journal of Political Science 37(2):391-414.

Rheault, Ludovic, Kaspar Beelen, Christopher Cochrane and Graeme Hirst. 2016. "Measuring emotion in parliamentary debates with automated textual analysis." PLOS One 11(12).

Ridout, Travis N. and Kathleen Searles. 2011. "It's my campaign I'll cry if I want to: How and when campaigns use emotional appeals." Political Psychology 32(3):439-458.

Ridout, Travis N. and Michael Franz. 2011. The Persuasive Power of Campaign Advertising. Philadelphia: Temple University Press. 
Roseman, Ira J., Robert P. Abelson and M. F. Ewing. 1986. Emotions and political cognition: Emotional appeals in political communication. In Political Cognition, ed. Richard Lau and David O. Sears. Hillsdale, NJ: Lawrence Erlbaum pp. 279-294.

Schenker, Nathaniel and Jane F. Gentleman. 2001. "On judging the significance of differences by examining the overlap between confidence intervals." The American Statistician 55:182-186.

Schofield, Norman J. 2003. "Valence competition in the spatial stochastic model." Journal of Theoretical Politics 15(4):371-383.

Schwarz, Norbert. 2000. "Emotion, cognition, and decision making." Cognition and Emotion 14(4):433440 .

Settle, Jaime E., Robert Bond, Lorenzo Coviello, Christopher J. Fariss, James Fowler, Jason Jones, Adam D. I. Kramer and Cameron Marlow. 2016. "From posting to voting: The effects of political competition on online political engagement." Political Science Research and Methods 4(2):361-378.

Skaperdas, Stergios and Bernard Grofman. 1995. "Modeling negative campaigning." American Political Science Review 89(1):49-61.

Tausczik, Yla R. and James W. Pennebaker. 2010. "The psychological meaning of words: LIWC and computerized text analysis methods." Journal of Language and Social Psychology 29(1):24-54.

Thomson, Robert, Terry Royed, Elin Naurin, Joaquín Artés, Rory Costello, Laurenz Ennser-Jedenastik, Mark Ferguson, Petia Kostadinova, Catherine Moury, François Pétry and Katrin Praprotnik. 2017. "The fulfillment of parties' election pledges: A comparative study on the impact of power sharing." American Journal of Political Science 61(3):527-542.

Utych, Stephen M. 2018. "Negative affective language in politics.” American Politics Research 46(1):77102.

van der Brug, Wouter, Cees van der Eijk and Mark Franklin. 2007. The Economy and the Vote: Economic Conditions and Elections in Fifteen Countries. New York: Cambridge University Press.

Vavreck, Lynn. 2009. The Message Matters: The Economy and Presidential Campaigns. New Jersey: Princeton University Press.

Weber, Christopher, Kathleen Searles and Travis N. Ridout. 2011. "More than a feeling: The strategic use and consequence of emotion in campaign advertisements." Paper presented at the 2011 Annual Meeting of the Midwest Political Science Association.

Williams, Laron K., Katsunori Seki and Guy D. Whitten. 2016. "You've got some explaining to do: The influence of economic conditions and spatial competition on party strategy." Political Science Research and Methods 4(1):47-63.

Wittman, Donald A. 1973. "Parties as utility maximizers." American Political Science Review 67(2):490498.

Wooldridge, Jeffrey. 2003. "Cluster-sample methods in applied econometrics." American Economic Review 2:329-341.

World Bank. 2012. World Development Indicators 2012 [Codebook]. Technical report.

Zaller, John. 1992. The Nature and Origins of Mass Opinion. New York: Cambridge University Press. 


\section{Online Appendix A: Finance Ministry Party}

The Prime Ministerial Party Hypothesis states that prime ministerial parties use higher levels of positive sentiment in their campaign messages than their coalition partners. Voters are likely to hold the prime ministerial party more responsible for the state of the world than its coalition partners. This is because the prime minister is the most visible member of the government and because the prime ministerial party is widely recognized as the agenda setter (Glasgow, Golder and Golder, 2011; Fortunato, Lin and Stevenson, 2013; Duch and Stevenson, 2013). Consistent with this, empirical evidence shows that the economic vote for the prime ministerial party is disproportionately high compared to that of other governmental parties (Duch and Stevenson, 2008; Debus, Stegmaier and Tosun, 2014).

Some scholars have suggested that voters may also attribute responsibility for the state of the world to the finance ministry party, particularly when it comes to the state of the economy (Williams, Seki and Whitten, 2016). However, the empirical support for this claim is rather mixed. For example, Debus, Stegmaier and Tosun (2014) find that there is no economic vote for the finance ministry party in Germany. In their more comprehensive study, Duch and Stevenson $(2008,269)$ conclude that while the finance ministry party experiences some of the economic vote, "most of it goes to the prime ministerial party." We claimed in the main text (see note 3) that, consistent with these previous studies, there is little evidence that parties controlling the finance ministry use higher levels of positive sentiment in their campaign messages than their coalition partners. We now turn to the basis for our claim.

In Table 3, we present the results from four different models where we examine the level of positive campaign sentiment found in the manifestos of incumbent parties, incumbent prime ministerial parties, and incumbent finance ministry parties. Data on incumbent finance ministry parties comes from Seki and Williams (2014). Model 1 in Table 3 acts as a baseline and simply reports the results from Model 2 in Table 2. While the results in Model 2 in Table 3 indicate that the level of positive sentiment exhibited by finance ministry parties is not significantly different from that exhibited by its coalition partners as a whole, those in Model 3 indicate that finance ministry parties still do not exhibit higher levels of positive sentiment than their coalition partners even when we separate out prime ministerial parties. These inferences are based on the fact that the coefficients on Incumbent Party $\times$ Finance Ministry Party are not statistically significant in either Model 2 or Model 3.

The additional interaction term in Model 4 allows us to examine whether the level of positive senti- 
Table 3: Positive Sentiment in European Party Manifestos

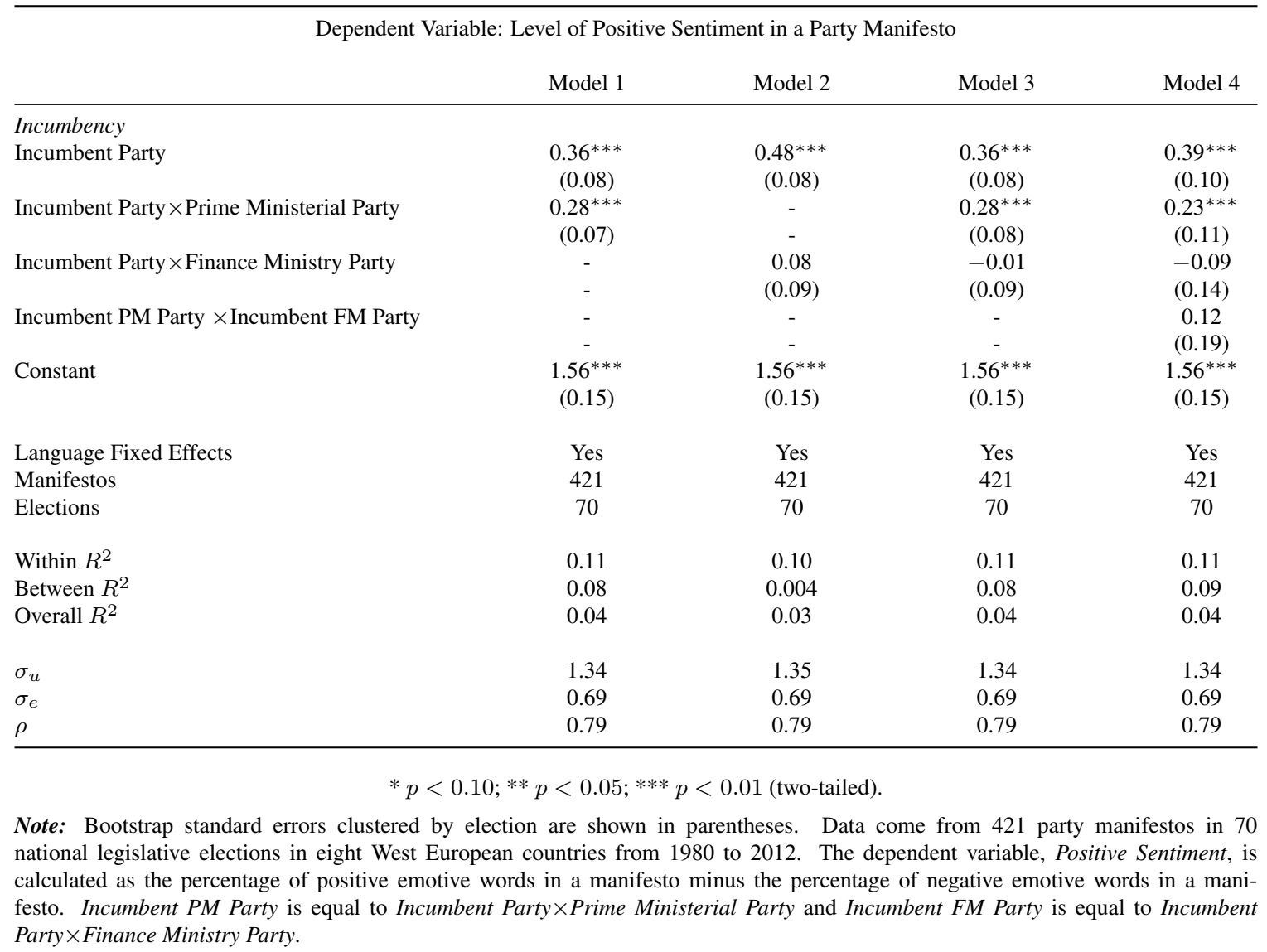

ment exhibited by a party in its manifesto depends on whether it controls both the finance ministry and the prime ministership or just the finance ministry but not the prime ministership. In our sample, there are 14 observations where a party controls the finance ministry but not the prime ministership and 21 observations where a party controls the prime ministership but not the finance ministry. The results in Model 4 show that controlling the finance ministry, either alone or in combination with the prime ministership, never changes the level of positive sentiment in a party's manifesto. This is indicated by the statistically insignificant coefficients on both Incumbent Party $\times$ Finance Ministry Party and Incumbent PM Party $\times$ Incumbent FM Party. Consistent with the Prime Ministerial Party Hypothesis and the discussion in the main text, though, the results presented in Table 3 indicate that prime ministerial parties always exhibit higher levels of positive sentiment in their manifestos than their coalition partners, even when they do not control the finance ministry. This is indicated by the positive and statistically significant coefficients on Incumbent Party $\times$ Prime Ministerial Party. 


\section{Online Appendix B: Positive Sentiment and Positive and Negative Words Scores}

In Online Appendix B, we provide more descriptive information on our measure of positive campaign sentiment. Recall that Positive Sentiment is calculated as the positive words score for a manifesto minus that manifesto's negative words score. Positive words scores refer to the percentage of positive emotive words in a manifesto, while negative words scores refer to the percentage of negative emotive words in a manifesto. The observed range for Positive Sentiment in our sample is $-0.68 \%$ to $7.60 \%$; the mean is $1.70 \%$ and the standard deviation is $1.45 \%$. The observed range for positive words score is $0.64 \%$ to $9.62 \%$; the mean is $3.02 \%$ and the standard deviation is $1.91 \%$. The observed range for negative words score is $0 \%$ to $5.22 \%$; the mean is $1.32 \%$ and the standard deviation is $0.79 \%$.

Figure 7: Histograms of Positive Sentiment and Positive and Negative Words Scores

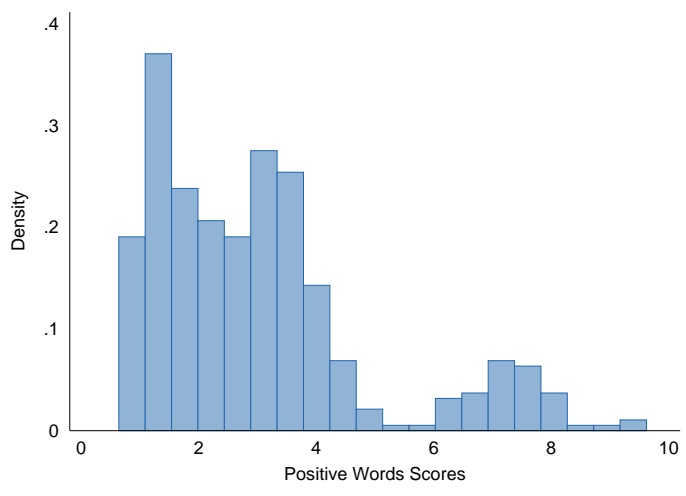

(a)

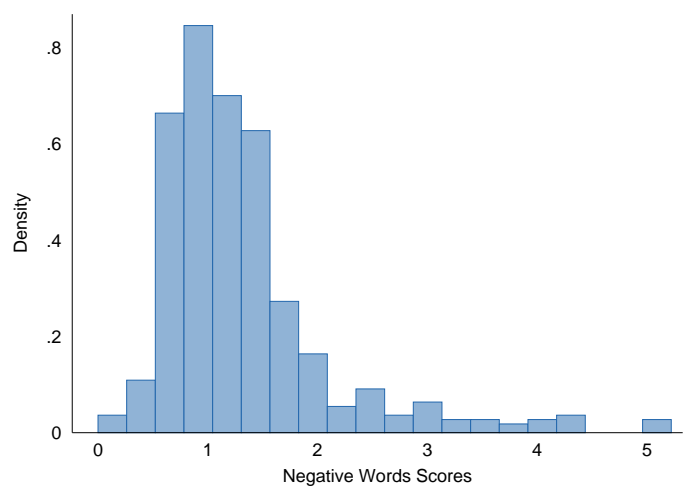

(b)

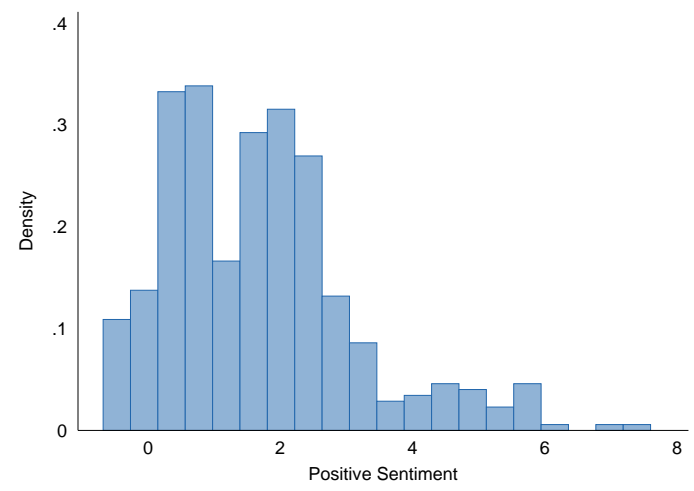

(c)

Note: Figure 7 shows a series of histograms for positive words scores (panel a), negative words scores (panel b), and Positive Sentiment (panel c) for 421 party manifestos in 70 national legislative elections in eight West European countries from 1980 to 2012. Positive words scores refer to the percentage of positive emotive words in a manifesto, while negative words scores refer to the percentage of negative emotive words in a manifesto. Positive Sentiment is calculated as the positive words score for a manifesto minus that manifesto's negative words score. 


\section{Online Appendix C: Fixed Effects}

In Appendix $\mathrm{C}$, we further examine the use of fixed effects in our model. In Table 2 in the main text, we present results from a model in which we employed language fixed effects and bootstrap standard errors clustered by election. The language fixed effects were included to take account of the fact that users of different languages differ in their underlying proclivity to employ positive and negative emotive words. We clustered the standard errors on elections to take account of the fact that the content and language used in party manifestos are unlikely to be independent within a given election. And we used bootstrap clustered standard errors as a conservative estimate of the size of the standard errors, as the literature is unclear as to when the number of clusters is sufficiently large to justify the asymptotic properties of traditional clusterrobust standard errors (Williams, 2000; Green and Vavreck, 2008; Esarey and Menger, 2018; Wooldridge, 2003, 135). ${ }^{1}$

\section{Language Fixed Effects}

There are several different ways to estimate a fixed effects model that produce identical results with respect to the estimated coefficients and standard errors. In Table 2 in the main text, we presented results from the 'within estimator' version of the fixed effects model, which treats our language fixed effects as nuisance parameters and removes them through mean-differencing (Cameron and Trivedi, 2009, 251). Our models were specified so that the coefficients on the constant terms indicated the average language fixed effects. It is also possible, though, to estimate a least-squares dummy-variable (LSDV) version of the fixed effects model that provides the individual estimates for the language fixed effects (Cameron and Trivedi, 2009, 253). For those who are interested, we now present the results from an LSDV version of our fixed effects model in Table 4. The models are specified with no constant so that we can estimate the intercepts for each language. Consistent with the 'language' information displayed in Figure 2 in the main text, English and Portuguese have the two largest fixed effects, while Dutch and Italian have the two smallest fixed effects.

As expected, all of the slope coefficients and standard errors shown in Table 4 are identical to those shown in the main text in Table 2. These are our primary parameters of interest, as they allow us to test our hypotheses. You'll notice, though, that the estimates of the $R^{2}$ differ across the two versions of the fixed effects model. This simply reflects the fact that the $R^{2}$ is calculated differently in the LSDV and the within

\footnotetext{
${ }^{1}$ As we note in the main text, our results are slightly stronger if we had employed traditional cluster-robust standard errors. Our inferences are also robust if we do not cluster our standard errors by election.
} 


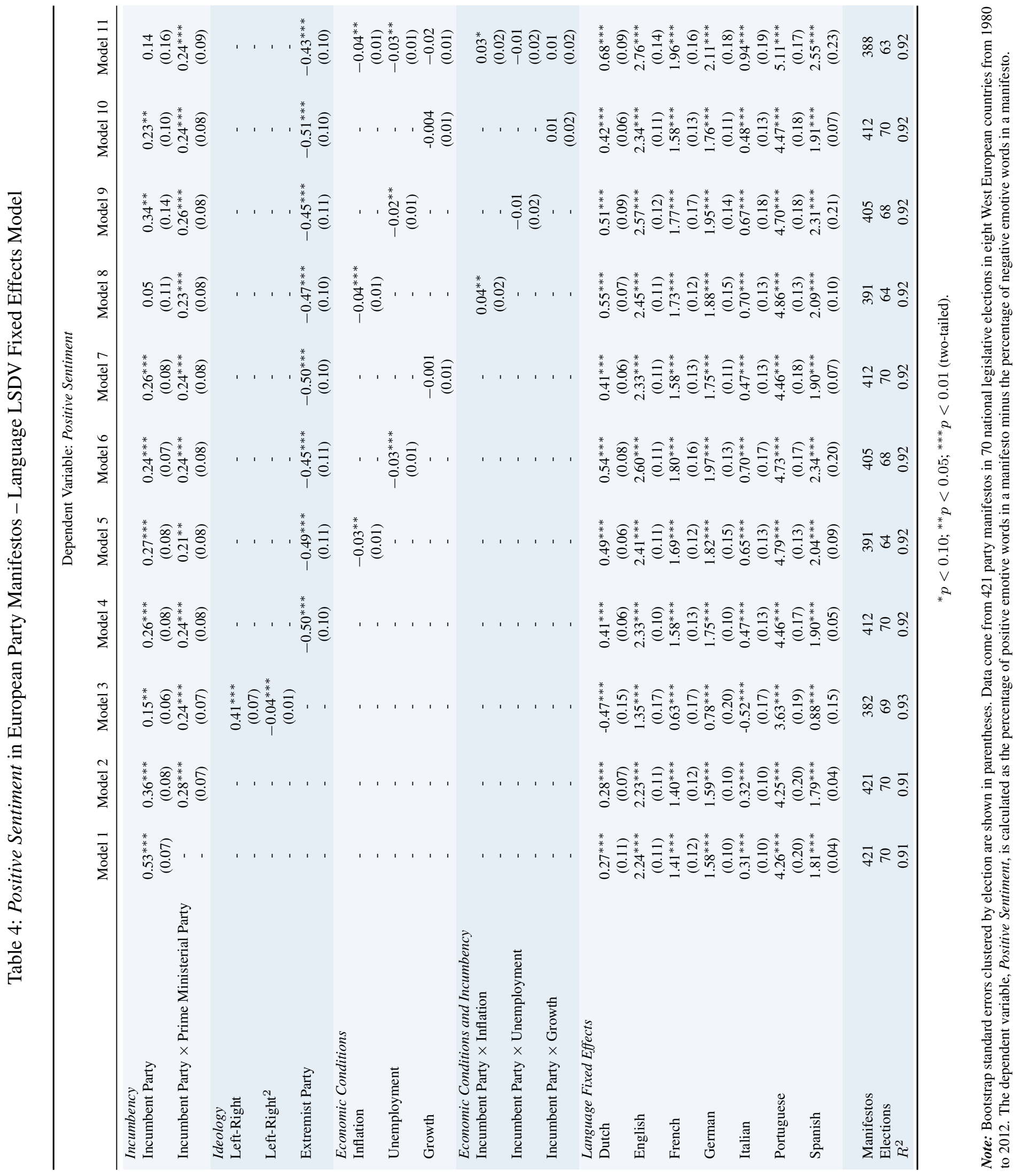


estimator models (Cameron and Trivedi, 2009, 258). Notably, the estimates of the 'within $R^{2}$ ' from the within estimator models are always smaller (never larger) than the equivalent estimates of the $R^{2}$ from the LSDV models. This is because the 'within estimator' models do not take account of the variance explained by the language fixed effects. There is a debate about the relative merits of the different $R^{2}$ statistics. We do not wish to take a position in this debate as we are more concerned with hypothesis testing and evaluating substantive effects than with prediction and model fit, and because there are reasons to question the informative value of all versions of the $R^{2}$ statistic (King, 1986, 1990, 1991). As a result, we report the $R^{2}$ from the within estimator models in Table 2 in the main text, and for those who are interested we provide the $R^{2}$ from the LSDV models in Table 4 here in Online Appendix C.

The LSDV fixed effects model does not provide estimates of $\sigma_{u}, \sigma_{e}$, and $\rho$. Recall that $\sigma_{u}$ indicates the standard deviation for the language fixed effects, while $\sigma_{e}$ indicates the standard deviation for the idiosyncratic error terms associated with the party manifestos. $\rho$ is the intraclass correlation coefficient and can be interpreted as the proportion of the total variance attributable to the language fixed effects.

\section{Country Fixed Effects}

In the main text (footnote 15), we noted that our results were robust to employing country fixed effects instead of language fixed effects. We now demonstrate this by reporting the results from a series of country fixed effects model specifications in Table 5. We employ the least-squares dummy-variable version of the fixed effects model with no constant so that we can estimate the intercepts for each country and compare our results to those shown in Table 4. The only change in the model specifications from the equivalent ones used in Table 4 is that we have separate fixed effects for Ireland and the United Kingdom; recall that in Table 4 the observations from Ireland and the United Kingdom shared the same English language fixed effect. The magnitude and statistical significance of the estimated coefficients in the country fixed effects models in Table 5 are qualitatively similar to the magnitude and statistical significance of the estimated coefficients in the language fixed effects model in Table 4. If anything, the magnitude of the coefficients on Incumbent Party is slightly larger in the country fixed effects model. The fact that the coefficients are similar across the language and country fixed effects models is not surprising given that the coefficients on the United Kingdom and Ireland country fixed effects are similar and that both sets of coefficients are similar to the English language fixed effects in Table 4. 


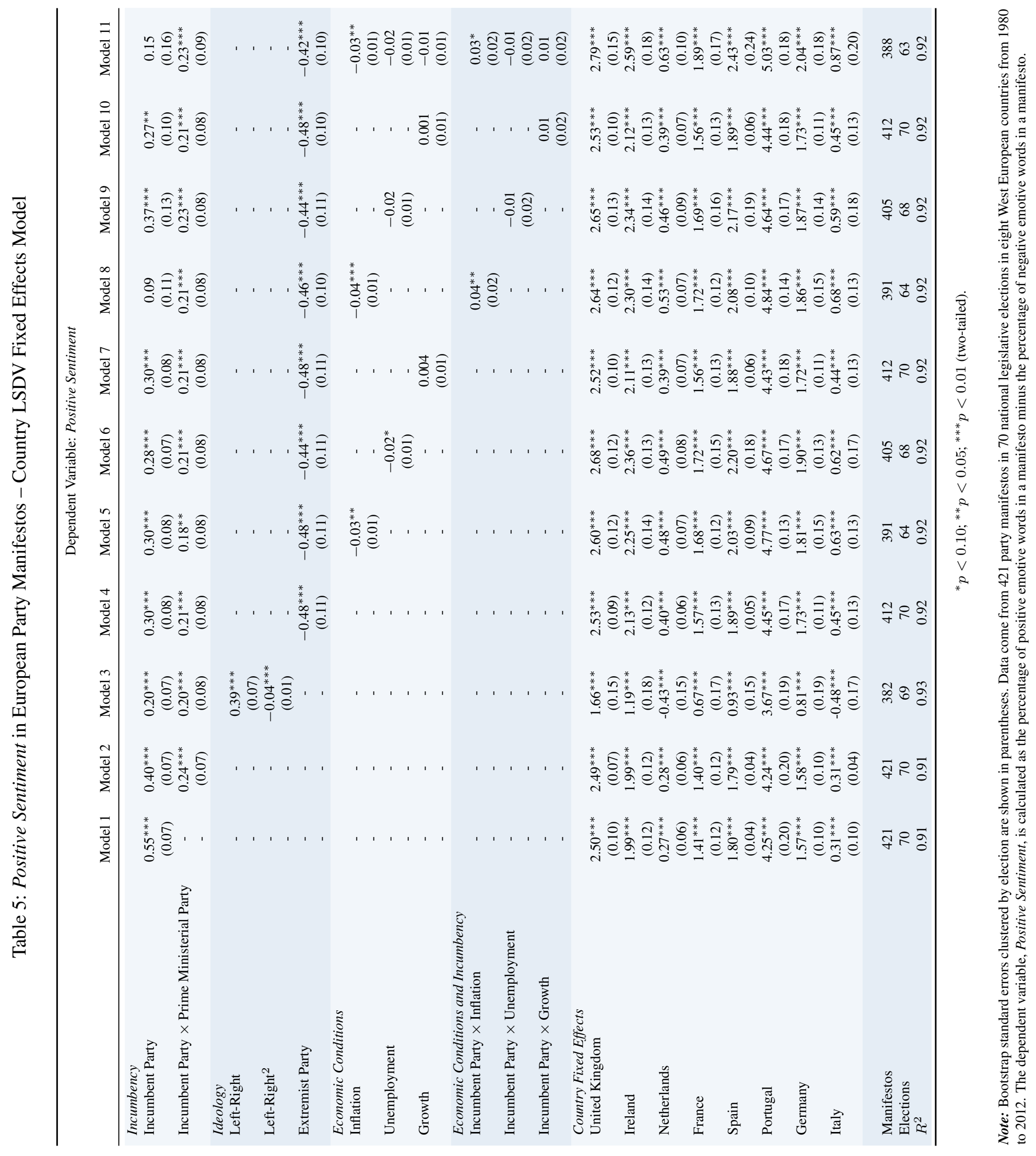




\section{Online Appendix D: A Case Study of the 2013 Elections in Germany}

To further evaluate our argument about the strategic use of campaign sentiment, we now briefly examine the September 22, 2013 German legislative elections. These elections occurred after the time period covered by the analyses in the main text and therefore represent a more rigorous 'out-of-sample' test of our argument (Gelman and Hill, 2006). At the time of the elections, there was an incumbent coalition government comprising the Christian Democrats (CDU/CSU) and Free Democrats (FDP). The prime ministerial position was held by Chancellor Angela Merkel of the Christian Democrats. The main opposition party was the Social Democrats (SPD), led by Peer Steinbrück. Of the remaining parties, the Greens, Alternative for Germany (AfD), the Left Party, and the Pirate Party were the most prominent. While the Greens might reasonably be considered a mainstream party, this is not the case for the other three parties. The Greens are a left of center environmental party promoting ecological and social sustainability. The AfD, which was founded in April 2013, is a right-wing populist party with strong anti-immigrant and eurosceptic tendencies. The Left Party is a left-wing populist party that traces its roots to the Party of Democratic Socialism (PDS), which governed communist East Germany during the Cold War. The Pirate Party, which was founded in 2006, is concerned with enhancing transparency and protecting civil rights in the age of the 'digital revolution' and does not fit easily onto the traditional left-right policy dimension. ${ }^{2}$

\section{Party Manifestos}

As indicated in the main text, party manifestos are the ideal form of campaign message for testing our hypotheses. This is because manifestos have several desirable properties that are not jointly shared by other types of campaign message. To summarize, manifestos provide parties with an opportunity to directly place their campaign strategy before voters in a carefully scripted way that is unfiltered by the media; they outline the overarching campaign strategy of parties in a way that, say, press releases, which often emerge irregularly throughout the campaign in response to ad hoc developments, might not; they are a type of campaign message that is used across Europe, thus facilitating cross-national comparison; and they are available for a long period of time, thereby allowing us to examine how the same parties change their use of campaign sentiment over time as they move in and out of office.

An analysis of the seven party manifestos used in the 2013 German elections provides strong support

\footnotetext{
${ }^{2}$ Our upcoming results are robust to the exclusion of the Pirate Party.
} 
for our theory about the strategic use of campaign sentiment. ${ }^{3}$ In line with our Incumbent Party Hypothesis, the level of positive sentiment employed by incumbent parties (1.41\%) is more than twice as high as that employed by opposition parties (0.68\%). ${ }^{4}$ In line with our Prime Ministerial Party Hypothesis, the level of positive sentiment employed by the prime ministerial party (1.70\%) is $53 \%$ higher than that employed by its coalition partner (1.11\%), and the level of positive sentiment employed by the non-prime ministerial incumbent party is $62 \%$ higher than that employed by opposition parties. Finally, in line with our Extreme Ideology Hypothesis, the level of positive sentiment employed by mainstream parties (1.24\%) is almost three times higher than that employed by the more ideologically extreme parties $(0.43 \%){ }^{5}$

In what follows, we discuss the use of emotive language in some of the other types of campaign messages - televised election debates, party election broadcasts, and party websites - that were used during the 2013 German elections. We also elaborate on why these other types of campaign messages are not ideal for testing our theory. Despite our concerns, the results provide broad support for our theoretical argument.

\section{Televised Election Debates}

Many European countries hold televised election debates. While there is some cross-national variation, it is clear that these debates are major campaign events that are watched by a large number of voters. For example, the first TV election debate in the UK took place in 2010 and was watched by 9.4 million people on average, or 37\% of the TV watching audience (Deans, 2010). The 2017 UK election debate drew a smaller, but not insignificant, peak audience of 4.7 million viewers (Shepherd, 2017). The presidential election debates that occur in France typically enjoy even higher TV audiences. For example, the 2017 presidential debate between Emmanuel Macron and Marine Le Pen drew an audience of 16.5 million viewers, more than $60 \%$ of the TV watching audience (Chrisafis, 2017). The 2013 German election debate between Angela Merkel and Peer Steinbrück was watched by an estimated 20 million viewers (Evans, 2013). Election debates offer political parties a good opportunity to present themselves and their policy platforms to the electorate in a partially unmediated way, and might be considered a 'mini version' of the election campaign.

\footnotetext{
${ }^{3}$ With the exception of the party manifesto published by Alternative for Germany ( 830 words), each of the manifestos in the 2013 German elections was quite long - the average word count for all seven manifestos was 40,635.

${ }^{4}$ Recall that the numbers in parentheses capture Positive Sentiment, which is calculated as the difference in the percentage of positive and negative words in a party manifesto. As indicated in the main text, the level of positive sentiment found in the party manifestos used in our statistical analyses ranges from $-0.68 \%$ to $7.60 \%$; the mean is $1.76 \%$ with a standard deviation of $1.45 \%$. As a result, the levels of positive sentiment observed in the 2013 party manifestos in Germany are not unusual.

${ }^{5}$ As with the upcoming analyses, we do not examine our Economic Performance Hypotheses as the state of the economy was fixed for all parties in the 2013 German elections.
} 
There are at least two reasons why using televised election debates to test our argument about the strategic use of emotive language in campaign messages is problematic, particularly in comparison to using party manifestos. First, the substantive content and style of election debates is rarely under the control of individual parties, and party leaders often find themselves responding on the fly to the issues and questions raised by, and language used by, debate moderators, their political opponents, and audience members. The face-to-face nature of campaign debates also encourages an active and confrontational approach that could reasonably cause candidates to adopt a different style of language to that used elsewhere in the campaign. Moreover, whereas parties can devote as much attention as they want to particular issues in their manifestos, election debates often force party leaders to talk about issues that are not central to their particular campaign. Each of the three election debates that took place in the UK in 2010, for example, focused on a different topic: domestic, international, and economic affairs. This format and these topics were the result of a negotiating process between the various political parties and media outlets involved in the 2010 debate.

Second, and more importantly, the heterogeneity in televised election debates, both within and across countries, as well as the relative novelty of these types of events in many European countries, makes drawing valid cross-national inferences difficult. Some countries have had televised election debates for many years. For example, France has held debates for every presidential election since 1974, while Germany has held them on and off for legislative elections since 1972. Other countries, though, have limited experience with election debates. The United Kingdom, for instance, has held election debates only since 2010. There is also significant variation in the number of debates per election and in the parties that are eligible, and who choose, to participate. Consider the case of the UK. There were three election debates prior to the 2010 elections in the UK, with only the Conservatives, Labour, and the Liberal Democrats allowed to participate. Prior to the 2015 elections, there were four debates, each with a different number of parties (ranging from seven to two) competing. Prior to the 2017 elections, there was just one election debate between the leaders of seven political parties; the incumbent Conservative prime minister, Theresa May, was absent after refusing to participate. The absence of incumbent or extremist parties in some of these UK debates means that it is difficult to test our Incumbent Party, Prime Ministerial Party, and Extreme Ideology Hypotheses.

Germany exhibits similar variation in the format of its election debates. From 1972, Germany started holding election debates, known as Elefantenrunden, in which all of the party leaders with legislative representation were eligible to participate (Anstead, Forthcoming, 9). These debates had no time limits and could last several hours. Election debates did not occur prior to the 1990, 1994, and 1998 elections, be- 
cause Chancellor Helmut Kohl refused to participate. Election debates returned in 2002 but now as a 'duel' (TV-Duell) between the leaders of the two largest parties - the leaders most likely to become Chancellor. In 2013, a debate similar to the old Elefantenrunden was added in which the leaders of the remaining legislative parties were able to participate. In 2013, therefore, there was a TV-Duell between the incumbent Christian Democrat Chancellor, Angela Merkel, and the leader of the Social Democrats, Peer Steinbrück, as well as a three-way contest (TV-Dreikampf) between the leaders of the Free Democrats, the Left Party, and the Greens. As they lacked legislative representation, Alternative for Germany and the Pirate Party were not eligible to participate in this second debate, making it harder to test our Extreme Ideology Hypothesis.

Our discussion here has focused on election debates in the United Kingdom and Germany. However, similar variation in debate formats exists in other European countries. As previously indicated, these differences make it difficult to conduct the types of cross-national analyses that appear in the main text. Indeed, this helps to partially explain the lack of 'comparative' research on televised election debates in the existing literature more generally. In his recent Scopus literature search, Anstead (Forthcoming, 3) finds that 166 articles were published on televised election debates between 2000 and 2015. Fully 80 of these articles focused entirely on the United States. Of the remaining articles, only five were 'comparative.' All five of these articles compared only two countries, and in four cases the second country was the United States.

With these provisos in hand, we now briefly examine the strategic use of emotive language in the debates that took place prior to the September 22, 2013 German elections. The TV-Duell between the CDU/CSU and the SPD took place on September 1 and lasted 90 minutes. The TV-Dreikampf between the FDP, the Left Party, and the Greens took place the next day on September 2 and lasted 60 minutes. Both debates were broadcast on four networks: ARD, ZDF, RTL, and ProSieben. After recording both debates, we transcribed them, separating out the comments associated with each party. We then ran each set of party comments through the LIWC automatic sentiment analysis program. The average number of words used by the parties in the $T V$-Duell was 6,166 ; it was 2,754 in the TV-Dreikampf.

The results strongly support our hypotheses. In line with our Incumbent Party Hypothesis, the level of positive sentiment employed by incumbent parties (1.39\%) was almost $60 \%$ higher than that employed by opposition parties (0.87\%). In line with our Prime Ministerial Party Hypothesis, the level of positive sentiment employed by the prime ministerial party (1.67\%) was about $50 \%$ higher than that employed by its coalition partner $(1.11 \%)$, and the level of positive sentiment employed by the non-prime ministerial incumbent party was $27.6 \%$ higher than that employed by the opposition parties. These levels of positive 
sentiment almost perfectly match those found in the party manifestos. Finally, in line with our Extreme Ideology Hypothesis, the level of positive sentiment employed by mainstream parties (1.25\%) was over three times higher than that employed by the more ideologically extreme parties $(0.39 \%)$. The magnitude of the difference in positive sentiment between the mainstream and extremist parties appears to be substantively larger during the election debates than in the party manifestos.

\section{The Effect of the Election Debate?}

In the main text, we took as our starting point the empirical observation in the existing literature that the emotive content of campaign messages has an impact on voter behavior (Marcus, Neuman and MacKuen, 2000; Brader, 2005, 2006; Brader and Marcus, 2013; Huddy and Gunnthorsdottir, 2000; Roseman, Abelson and Ewing, 1986; Weber, Searles and Ridout, 2011; Utych, 2018). We also took as a our starting point the empirical observation that language can engender different emotions (Pennebaker, 1993; Pennebaker and Francis, 1996; Tausczik and Pennebaker, 2010) and thereby shape individual perceptions of the political world around them (Edelman, 1964, 1977). We did not seek to replicate these findings. Instead, we argued that if these empirical findings were correct, then parties should be strategic in their use of campaign sentiment. We then set out to test whether this is, indeed, the case.

We now take this opportunity, though, to reanalyze the results of an experiment conducted during the 2013 election debates in Germany that are consistent with previous empirical findings showing how campaign sentiment can influence how individuals evaluate the state of the world. The experiment, which we did not design, was done in the context of the German Longitudinal Election Study that accompanied the 2013 elections. Our data come from the first two waves of a panel study (ZA5709), which asked participants the same series of questions just prior to (wave 1) and just after (wave 2) the TV-Duell between the leaders of the CDU and SPD. Several of these questions pertained to the economy and the performance of the government. This setup can be considered a pre-post experimental design with the debate as the treatment.

If party leaders who use higher levels of positive sentiment engender a more positive outlook towards the world in their supporters than those who do not, then this would be consistent with the existing empirical literature discussing the impact of campaign sentiment on voter behavior. We know from the debate that Chancellor Angela Merkel (CDU) employed 25\% more positive emotive language than her opponent, Peer Steinbrück (SPD). As a result, we might expect to see the prime minister's supporters increase their evaluation of the economy and the government over the course of the debate more than supporters of her 
opponent. This is precisely what we find. Specifically, we ran the following regression model,

$$
\text { Evaluation }_{t 2}-\text { Evaluation }_{t 1}=\beta_{0}+\beta_{1} \text { PM Supporter }+\epsilon
$$

where Evaluation refers to a respondent's evaluation of the economy or government performance, $t 2$ refers to the post-debate period, $t 1$ refers to the pre-debate period, and PM Supporter is a dichotomous variable, measured at $t 1$ prior to the debate, that equals one if the respondent supports Merkel and 0 if the respondent supports Steinbrück. For Evaluation, we use three different questions that get at retrospective, current, and prospective evaluations of the economy, two questions that get at the respondent's own economic well-being, and one question evaluating government performance. As predicted, the coefficient on PM Supporter, $\beta_{1}$, is positive in all six cases, indicating that Merkel's supporters improve their evaluation of the state of the world during the course of the debate. It is statistically significant when evaluating the state of the current economy, but does not quite reach conventional levels of statistical significance in the other cases.

We recognize that the design of this particular experiment is not ideal for testing the empirical claim that motivates our own statistical analysis, namely that the emotive content of campaign messages can influence voter behavior and their evaluation of the state of the world. For example, it may be the case that participants are responding to the content of what the two candidates are saying as opposed to the emotive language through which that content is conveyed. Nonetheless, the results are suggestive, and they are consistent with the underlying premise that motivates our interest in analyzing the strategic use of campaign sentiment.

\section{Party Election Broadcasts}

As noted in the main text, there is considerable cross-national variation in how political election broadcasts (PEBs) are regulated on television (Kaid and Holtz-Bacha, 2006). Some countries like Switzerland, for example, ban all forms of political advertising on television (and radio). PEBs are not officially banned in Denmark, but political actors have historically agreed not to use them for campaigning purposes (Kaid and Holtz-Bacha, 2006, 5). While some countries ban 'paid' political advertising on public and commercial television (France, Portugal, Spain, the United Kingdom), others allow it but only on commercial television (Germany, Italy, and the Netherlands). Many European countries provide 'free', but rationed, political advertising, typically on public television, but there remains significant heterogeneity, both within and across 
countries, when it comes to things like the number of slots allocated to parties and the length of individual broadcasts. This variation makes it difficult to draw valid cross-national inferences about the strategic use of campaign sentiment from party election broadcasts. Note also that we are interested in the use of emotive language in campaign messages. As previous research has indicated (Huddy and Gunnthorsdottir, 2000; Brader, 2006), much of the emotive content in PEBs comes from the imagery and music that is employed. From a practical point of view, the limited number of words employed in a typical PEB also raises concerns about the reliability of automatic sentiment analysis programs like LIWC (see note10).

On the whole, party election broadcasts play only a limited role during German election campaigns. Indeed, each party typically releases only one broadcast of up to 90 seconds for the entire campaign (Schultheis, 2013). In 2013, the average number of words used in a party election broadcast for the seven parties under consideration here was just $195(\sigma=53)$. The word counts ranged from a low of 130 for the Pirate Party and Alternative for Germany to a high of 269 for the SPD. ${ }^{6}$ Each party is able to air their election broadcast for free on the two public television networks, ZDF and ARD. The number of times that each party can air their broadcast depends on their vote-share in the previous election and their status in the parliament, with a minimum of two for any party eligible to compete in the elections. In addition, the largest parties cannot have more than four times the number of election broadcasts as the smallest party. In 2013, this meant that the two largest parties, the Christian Democrats and the Social Democrats, were able to air their single broadcast eight times on both ZDF and ARD; the Free Democrats, the Greens, and the Left Party were able to air their election broadcast four times on each network; and Alternative for Germany and the Pirate Party were able to air their broadcast just twice on each network (Medienanstalten, 2013). ${ }^{7}$ Political parties in Germany, unlike those in France, Portugal, Spain, and the United Kingdom, can also purchase air time on commercial television. Typically, German parties run a shortened $30-60$ second version of the same election broadcast that is aired on public television. Given their limited campaign budgets, German parties do not invest heavily in 'paid' television advertising, preferring to focus their resources on putting up campaign posters and billboards. The Kölner Stadt-Anzeiger estimates that the Social Democrats ran their PEB 176 times on commercial television during the 2013 campaign and that the Christian Democrats ran their PEB 140 times (Doemans, 2013). Given the costs, smaller parties ran considerably fewer election

\footnotetext{
${ }^{6}$ Recall that the average number of words in the party manifestos used in our statistical analyses in the main test was $21,979$.

${ }^{7}$ Party election broadcasts usually appear on television between $6 \mathrm{pm}$ and $11 \mathrm{pm}$ in the evening. The exact timing and sequence of the party election broadcasts is determined randomly by the public television networks. Each election broadcast is introduced by an official announcement to separate it from the normal broadcast content (Schweitzer, 2008, 240).
} 
broadcasts on commercial television.

Despite our misgivings about using party election broadcasts to examine the strategic use of emotive language, we transcribed the 2013 PEBs of the CDU, the SPD, the FDP, the Greens, the Left Party, the Pirate Party, and AfD, and ran them through the LIWC automatic sentiment analysis program. ${ }^{8}$ The results strongly support our hypotheses. In line with the Incumbent Party Hypothesis, the level of positive sentiment employed by incumbent parties in their election broadcasts $(5.1 \%)$ is almost three times higher than that employed by opposition parties (1.76\%). In line with our Prime Ministerial Party Hypothesis, the level of positive sentiment employed by the prime ministerial party $(5.82 \%)$ is one third higher than that employed by its coalition partner (4.37\%), and the level of positive sentiment employed by the non-prime ministerial incumbent party is more than twice that employed by opposition parties. Finally, in line with our Extreme Ideology Hypothesis, the level of positive sentiment employed by mainstream parties (3.64\%) is $80 \%$ higher than that employed by the more ideologically extreme parties $(2.02 \%)$.

\section{Party Websites}

Internet campaigning provides parties with an opportunity to circumvent the filters of traditional media outlets and directly present their messages to voters. It also provides parties with an opportunity to try to shape how the traditional media outlets portray them. In this sense, internet campaign messages offer a potentially useful insight into the strategic decisions of political parties regarding campaign sentiment. However, there are a number of limitations associated with using internet campaign messages in this regard, particularly relative to using party manifestos. The first has to do with the novelty and rapidly evolving nature of internet campaigning. A consequence is that we have very few national-level elections, particularly in Europe, in which internet campaign messages have played a significant role. One can increase the number of available observations by examining individual party candidates (Zittel, 2009, 2015), but the focus here is on political parties acting at the national level. A second limitation is that there is significant variation, both across countries and within countries, with respect to the extent to which parties use tools such as websites and social media, even in their more recent election campaigns (Gibson, 2004; Gibson and Römmele, 2009; Obholzer and Daniel, 2016). A more practical limitation is that many uses of social media, such as Tweets, involve few words, making it difficult for automatic sentiment analysis tools to reliably capture the emotive content of individual messages.

\footnotetext{
${ }^{8}$ Each of the party election broadcasts can be viewed online here.
} 
Despite these limitations, we now briefly examine the use of internet campaigning in Germany, and in particular, party websites during the 2013 federal elections. National parties in Germany began to develop their online presence in the mid-1990s. However, it was not until the 2002 elections that Germany had its "first professional online campaign" (Schweitzer, 2008, 242). Only in the 2009 elections, following the widely publicized success of Obama's internet campaign in the United States in 2008, did German parties begin to incorporate web 2.0 tools, such as blogs, Twitter, and Facebook, into their online election campaigns (Jungherr, 2015). Digital tools were further integrated into party campaign strategies in the lead-up to the 2013 elections. The extent to which internet campaigning has been adopted and exactly how digital tools are used varies across different political parties (Jungherr, 2016).

Despite the increased availability and use of digital tools, there is a strong consensus that these methods have not fundamentally changed the traditional style of German election campaigns, which continues to focus on billboards, press coverage, and televised campaigning. ${ }^{9}$ In effect, internet campaigning is considered supplemental, rather than central, to the election campaigns of German parties. Consumption of internet campaigning in Germany also remains relatively low compared to the consumption of political news via more traditional media outlets. In the two months prior to the 2013 elections, for example, $60 \%$ of Germans used local and regional newspapers to keep abreast of the election campaign and $80 \%$ watched political developments on one of the two main public networks, ARD and ZDF. In contrast, only 10\% of Germans claimed to follow the election campaign via social networking sites such as Facebook or Twitter (Partheymüller and Schäfer, 2013). The impact of internet campaigning on election outcomes has also been challenged. For instance, there is little evidence that internet campaigning is related to election outcomes at the federal, regional, or local levels in Germany (Marcinkowski and Metag, 2013). Some studies, though, suggest that internet campaigning in Germany can help mobilize voters indirectly by increasing media attention and by shaping media narratives (Flemming, Metag and Marcinkowski, 2013; Jungherr, 2016).

Drawing on in-depth interviews with key campaign personnel, Jungherr (2016) finds that websites were central to, and the most visible elements in, the online campaigns of German parties during the 2013 elections. His conclusion that "websites came to mirror the central narrative of each campaign" (365) is not surprising given that campaign personnel at the time saw no distinction between their traditional election campaign tactics and their online activity. Given this, we now use party websites to examine the strategic

\footnotetext{
${ }^{9}$ This was the conclusion reached by analyses of internet campaigning in the 2002 and 2005 elections (Schweitzer, 2008), as well as the more recent 2009 (Jungherr, 2015) and 2013 (Jungherr, 2016) elections.
} 
use of emotive language in the internet campaigning of German parties. As German election campaigns are short, with much of the active campaigning occurring in the last few weeks, we chose to examine German party websites during the last four weeks of the 2013 election campaign. ${ }^{10}$

Before presenting our results, there are several things to note about our analysis of German party websites. The first is that our emphasis on the text found on party websites means that we are ignoring how the use of images and videos can engender particular emotions and shape campaign sentiment. This is quite pertinent as the CDU provided a large number of Youtube videos on its website and the SPD frequently used short video clips to highlight the activities of its party leader (Jungherr, 2016, 370). The second is that the websites sometimes contain interactive content, with the consequence that some of the archived text may not come from the parties. The third thing to note is that any analysis of party websites has to decide how much of the website to examine. How deep - how many mouse clicks from the homepage - should one go? Should we include the material that is directly linked to from each website? The variation in the structure of the different websites complicates these choices. Given our purposes here, we saw no principled theoretical criteria for making these types of choices. To achieve some minimal degree of comparability across the German party websites, we therefore decided to examine only the text that appeared on each party's main page about a month (August 24) before the election. ${ }^{11}$ The average number of words on a party's main page was 855 , ranging from a low of 394 words for the Left Party page to a high of 1886 words for the SPD page.

On the whole, the results of our analysis of party websites are supportive of our hypotheses. In line with our Incumbent Party Hypothesis, the level of positive sentiment employed by incumbent parties $(2.00 \%)$ is almost five times higher than that employed by opposition parties $(0.42 \%)$. Contrary to our Prime Ministerial Party Hypothesis, the level of positive sentiment employed by the prime ministerial party $(1.55 \%)$ is less than that employed by its coalition partner (2.44\%). However, as predicted, both incumbent parties exhibit more positive sentiment than each of the opposition parties. Finally, in line with our Extreme Ideology Hypothesis, the level of positive sentiment employed by mainstream parties on their website $(1.30 \%)$ is over four times higher than that employed by the more ideologically extreme parties $(0.30 \%)$.

\footnotetext{
${ }^{10}$ The websites were archived using GNU Wget (https://www.gnu.org/software/wget/). The raw .html files were then converted into . txt files using pandoc (https://pandoc.org/). Finally, the . txt files were then run through the LIWC automatic sentiment analysis program.

${ }^{11}$ The parties should have had enough time to tailor their webpages to their electoral campaigns by this date. There appears to have been only marginal changes to the text found on the party main pages after this date.
} 


\section{Conclusion}

In this brief case study of the 2013 German elections, we provided additional information to support our argument in the main text. First, reanalyzing individual-level experimental data from the 2013 German Longitudinal Election Study (GLES), we presented evidence consistent with the literature's claim that campaign sentiment can influence how individuals evaluate the state of the world. Second, we examined the campaign sentiment used in different types of campaign messages - party manifestos, televised election debates, party election broadcasts, and party websites. In almost every case, the results of our analyses provided support for our Incumbent Party Hypothesis, our Prime Ministerial Party Hypothesis, and our Extreme Ideology Hypothesis. These particular results, when taken together, are consistent with our claim that the language and campaign messages found in manifestos are repeated when parties "communicate to the public via other avenues, such as campaign advertisements, party elites' campaign speeches, and media interviews" (Adams, Ezrow and Somer-Topcu, 2011, 372). 


\section{Online Appendices: References}

Adams, James, Lawrence Ezrow and Zeynep Somer-Topcu. 2011. "Is anybody listening? Evidence that voters do not respond to European parties' policy statement during elections." American Journal of Political Science 55(2):370-382.

Anstead, Nick. Forthcoming. "A different beast? Televised election debates in parliamentary democracies." International Journal of Press/Politics .

Brader, Ted. 2005. "Striking a responsive chord: How political ads motivate and persuade voters by appealing to emotions." American Journal of Political Science 49(2):388-405.

Brader, Ted. 2006. Campaigning for Hearts and Minds: How Emotional Appeals in Political Ads Work. New York: Cambridge University Press.

Brader, Ted and George E. Marcus. 2013. Emotions and Political Psychology. In The Oxford Handbook of Political Psychology, ed. Leonie Huddy, David O. Sears and Jack S. Levy. Oxford: Oxford University Press pp. 165-204.

Cameron, A. Colin and Pravin K. Trivedi. 2009. Microeconometrics Using Stata. College Station: Stata Press.

Chrisafis, Angelique. 2017. "French election: Macron hailed as winner of bruising Le Pen TV debate." The Guardian, May 4.

Deans, Jason. 2010. “Leaders' debate TV ratings: 9.4m viewers make clash day's biggest show." The Guardian, April 16.

Debus, Marc, Mary Stegmaier and Jale Tosun. 2014. "Economic voting under coalition governments: Evidence from Germany." Political Science Research and Methods 2(1):49-67.

Doemans, Von Karl. 2013. "Wahlwerbespots der Parteien: Viel Merkel, wenig Steinbrück." Kölner StadtAnzeiger, August 23.

Duch, Raymond M. and Randolph T. Stevenson. 2008. The Economic Vote: How Political and Economic Institutions Condition Election Results. New York: Cambridge University Press.

Duch, Raymond and Randolph T. Stevenson. 2013. "Voter perceptions of agenda power and attribution of responsibility for economic performance." Electoral Studies 32:512-516.

Edelman, Murray. 1964. The Symbolic Use of Politics. Urbana: University of Illinois Press.

Edelman, Murray. 1977. Political Language: Words that Succeed and Policies that Fail. London: Academic Press.

Esarey, Justin and Andrew Menger. 2018. "Practical and effective approaches to dealing with clustered data." Political Science Research and Methods .

Evans, Stephen. 2013. "German election: Merkel battles Steinbrück in TV duel.” BBC Online, September 2.

Flemming, Felix, Julia Metag and Frank Marcinkowski. 2013. "The interplay of mass media and online campaigning: Evidence from a German state election." Paper presented at the ECREA Conference "New Trends in Political Communication: Evidence, Theories, Implications, Opportunities", Milan, Italy. 
Fortunato, David, Nick Lin and Randolph Stevenson. 2013. "Political knowledge in coalitional democracies.” Working paper, Rice University.

Gelman, Andrew and Jennifer Hill. 2006. Data Analysis Using Regression and Multilevel/Hierarchical Models. Cambridge University Press.

Gibson, Rachel. 2004. "Web campaigning from a global perspective." Asia-Pacific Review 11(1):95-126.

Gibson, Rachel and Andrea Römmele. 2009. "Measuring the professionalization of political campaigning." Party Politics 15(3):265-293.

Glasgow, Garrett, Matt Golder and Sona N. Golder. 2011. "Who "wins"? Determining the party of the prime minister." American Journal of Political Science 55(4):937-954.

Green, Donald P. and Lynn Vavreck. 2008. "Analysis of cluster-randomized experiments: A comparison of alternative estimation approaches." Political Analysis 16(2):138-152.

Huddy, Leonie and Anna H. Gunnthorsdottir. 2000. "The persuasive effects of emotive visual imagery: Superficial manipulation or the product of passionate reason?" Political Psychology 21(4):745-778.

Jungherr, Andreas. 2015. "The role of the internet in political campaigns in Germany." German Politics 24(4):427-434.

Jungherr, Andreas. 2016. "Four functions of digital tools in election campaigns: The German case." International Journal of Press/Politics 21(3):358-377.

Kaid, Lynda Lee and Christina Holtz-Bacha, eds. 2006. The Sage Handbook of Political Advertising. London: Sage Publications, Inc.

King, Gary. 1986. "How not to lie with statistics: Avoiding common mistakes in quantitative political science." American Journal of Political Science 30(3):666-687.

King, Gary. 1990. "Stochastic variation: A comment on Lewis-Beck and Skalaban's 'The R-squared'." Political Analysis 2(1):185-200.

King, Gary. 1991. “'Truth' is stranger than prediction, more questionable than causal inference.” American Journal of Political Science 35(4):1047-1053.

Marcinkowski, Frank and Julia Metag. 2013. "Lassen sich mit dem Internet Wählerstimmen gewinnen?" Publizistik 58(1):23-44.

Marcus, George E., W. Russell Neuman and Michael MacKuen. 2000. Affective Intelligence and Political Judgment. New York: Cambridge University Press.

Medienanstalten, Die. 2013. "Rechtliche Hinweise der Landesmedienanstalten zu den Wahlsendezeiten für politische Parteien im bundesweit verbreiteten privaten Rundfunk.” March 19.

Obholzer, Lukas and William T. Daniel. 2016. “An online electoral connection? How electoral systems condition representatives' social media use.” European Union Politics 17(3):387-407.

Partheymüller, Julia and Anne Schäfer. 2013. "Das Informationsverhalten der Bürger im Bundestagswahlkampf 2013." Media Perspecktiven 12:574-588.

Pennebaker, James W. 1993. "Putting stress into words: Health, linguistic, and therapeutic implications." Behaviour Research and Therapy 31(6):539-548. 
Pennebaker, James W. and Martha E. Francis. 1996. "Cognitive, emotional, and language processes in disclosure." Cognition and Emotion 10(6):601-626.

Roseman, Ira J., Robert P. Abelson and M. F. Ewing. 1986. Emotions and political cognition: Emotional appeals in political communication. In Political Cognition, ed. Richard Lau and David O. Sears. Hillsdale, NJ: Lawrence Erlbaum pp. 279-294.

Schultheis, Emily. 2013. "In Germany, one TV ad per candidate.” Politico, September 13.

Schweitzer, Eva Johanna. 2008. Germany: Online Campaign Professionalism in the 2002 and 2005 National Elections. In Making a Difference: A Comparative View of the Role of the Internet in Election Politics, ed. Richard Davis, Diana Owen and David Taras. New York: Rowman \& Littlefield pp. 235-256.

Seki, Katsunori and Laron K. Williams. 2014. "Updating the Party Government data set." Electoral Studies $34: 270-279$.

Shepherd, Jack. 2017. "BBC Debate beaten by Britain's Got Talent in the ratings.” The Independent, April 16.

Tausczik, Yla R. and James W. Pennebaker. 2010. "The psychological meaning of words: LIWC and computerized text analysis methods." Journal of Language and Social Psychology 29(1):24-54.

Utych, Stephen M. 2018. "Negative affective language in politics.” American Politics Research 46(1):77102.

Weber, Christopher, Kathleen Searles and Travis N. Ridout. 2011. "More than a feeling: The strategic use and consequence of emotion in campaign advertisements." Paper presented at the 2011 Annual Meeting of the Midwest Political Science Association.

Williams, Laron K., Katsunori Seki and Guy D. Whitten. 2016. "You've got some explaining to do: The influence of economic conditions and spatial competition on party strategy." Political Science Research and Methods 4(1):47-63.

Williams, Rick L. 2000. "A note on robust variance estimation for cluster-correlated data." Biometrics 56:645-646.

Wooldridge, Jeffrey. 2003. "Cluster-sample methods in applied econometrics." American Economic Review 2:329-341.

Zittel, Thomas. 2009. "Lost in technology? Political parties and the online campaigns of constituency candidates in Germany's mixed member electoral system." Journal of International Politics and Technology 6(3-4):298-311.

Zittel, Thomas. 2015. "Do candidates seek personal votes on the internet? Constituency candidates in the 2009 German federal elections." German Politics 24(4):435-450. 